\title{
Culturable Microorganisms Associated with Sea Cucumbers and Microbial Natural Products
}

\author{
Lei Chen * $\mathbb{0}$, Xiao-Yu Wang, Run-Ze Liu and Guang-Yu Wang *
}

Department of Bioengineering, School of Marine Science and Technology, Harbin Institute of Technology at Weihai, Weihai 264209, China; wangxiaoyu2020@stu.hit.edu.cn (X.-Y.W.); liurunze2017@stu.hit.edu.cn (R.-Z.L.)

* Correspondence: chenlei18@hit.edu.cn or chenleihit@163.com (L.C.); wanggy@hit.edu.cn or wanggy18_2007@163.com (G.-Y.W.); Tel.: +86-631-5687076 (L.C.); +86-631-5682925 (G.-Y.W.)

\begin{abstract}
Sea cucumbers are a class of marine invertebrates and a source of food and drug. Numerous microorganisms are associated with sea cucumbers. Seventy-eight genera of bacteria belonging to 47 families in four phyla, and 29 genera of fungi belonging to 24 families in the phylum Ascomycota have been cultured from sea cucumbers. Sea-cucumber-associated microorganisms produce diverse secondary metabolites with various biological activities, including cytotoxic, antimicrobial, enzymeinhibiting, and antiangiogenic activities. In this review, we present the current list of the 145 natural products from microorganisms associated with sea cucumbers, which include primarily polyketides, as well as alkaloids and terpenoids. These results indicate the potential of the microorganisms associated with sea cucumbers as sources of bioactive natural products.
\end{abstract}

Keywords: sea cucumber; bioactivity; diversity; microorganism; polyketides; alkaloids

Citation: Chen, L.; Wang, X.-Y.; Liu, R.-Z.; Wang, G.-Y. Culturable Microorganisms Associated with Sea Cucumbers and Microbial Natural Products. Mar. Drugs 2021, 19, 461. https://doi.org/10.3390/md19080461

Academic Editor: Khaled A. Shaaban

Received: 20 July 2021

Accepted: 13 August 2021

Published: 16 August 2021

Publisher's Note: MDPI stays neutral with regard to jurisdictional claims in published maps and institutional affiliations.

Copyright: () 2021 by the authors. Licensee MDPI, Basel, Switzerland. This article is an open access article distributed under the terms and conditions of the Creative Commons Attribution (CC BY) license (https:// creativecommons.org/licenses/by/ $4.0 /)$.

\section{Introduction}

Sea cucumbers are marine invertebrates that belong to the class Holothuroidea of the phylum Echinodermata. Globally, there are about 1500 species of sea cucumbers [1], which are divided into three subclasses: Aspidochirotacea, Apodacea, and Dendrochirotacea, and can be further divided into six orders: Aspidochirotida, Elasipodida, Apodida, Molpadida, Dendrochirotida, and Dactylochirotida [2].

Sea cucumbers are found in benthic areas and the deep sea worldwide [3]. They play an important role in marine ecosystems and occupy a similar niche to earthworms in terrestrial ecosystems [4]. Sea cucumbers obtain food by ingesting marine sediments or filtering seawater [5] and provide a unique, fertile habitat for a variety of microorganisms, including bacteria and fungi [6]. However, since most microorganisms are unculturable under conventional laboratory conditions [7], this review primarily focuses on culturable sea-cucumber-associated microorganisms.

Sea cucumbers have been used in medicine in Asia for a long time [8]. For example, an ointment derived from the sea cucumber Stichopus sp. 1 is used to treat back and joint pain in Malaysia [9]. Compounds isolated from sea cucumbers have a variety of biological and pharmacological activities, such as anticancer, antiangiogenic, anticoagulant/antithrombotic, antioxidant, antiinflammatory, antimicrobial, antihypertension, and radioprotective properties [10,11]. A phase II clinical trial of a sea cucumber extract, called TBL-12, has been conducted in patients with untreated asymptomatic myeloma [12]. Many studies have shown that the microorganisms associated with marine animals, such as sponges and ascidians, are the true producers of marine natural products [13-16]. Therefore, investigating sea-cucumber-associated microorganisms is essential for discovering new compounds with potential as novel active drugs. For the past 20 years, there has been an increasing effort made by researchers on diversity and bioactive compounds of microorganisms associated with sea cucumber. However, previously, no comprehensive review article as such has ever been published about this field. 
This review discusses the biodiversity of the culturable microorganisms associated with sea cucumbers and the chemical structure and bioactive properties of the secondary metabolites produced by these microorganisms.

\section{Microorganisms Associated with Sea Cucumbers}

\subsection{Geographical Distribution of Microorganisms Associated with Sea Cucumbers}

Although sea cucumbers are distributed in oceans worldwide [3], most studies on the biological and chemical diversity of sea-cucumber-associated microorganisms have focused on species in the northern temperate areas and tropical areas of the eastern hemisphere [17-26]. More than $80 \%$ of the sampling sites are located on the west coast of the Pacific Ocean. However, a small number of sampling sites are also located in the Atlantic, Indian, and Antarctic Oceans [17-26] (Figure 1 and Table S1). Sea cucumber samples are typically collected from the coast at a depth of less than $20 \mathrm{~m}$ [17-21].

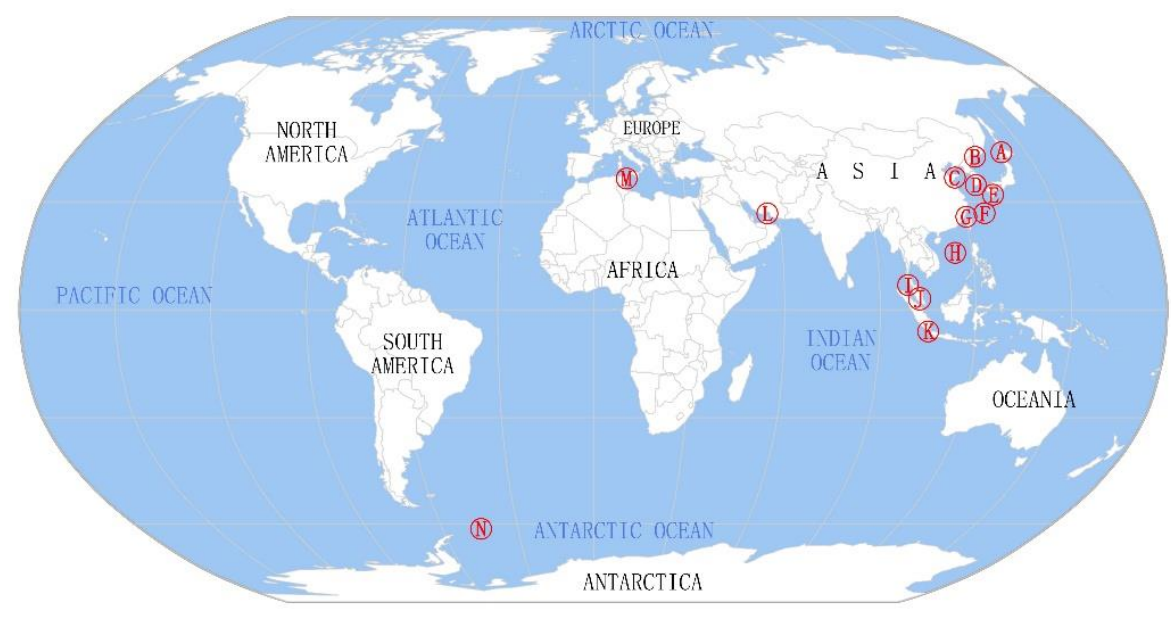

Figure 1. Geographical distribution of sea cucumber samples used for studies of culturable microorganisms. The red circles represent sampling sites: (A) Funka Bay and Ainuma fishing port, Hokkaido, Japan; (B) Sea of Japan, Russia; (C) Yellow Sea, China; (D) Geomun-do, Yeosu, Korea; (E) Kushima, Omura; Koecho; Nagasaki; Japan; (F) Coast of Aka Island, Okinawa prefecture, Japan; (G) Ningde, Fujian, China; (H) South China Sea, China; (I) Dayang Bunting Island, Yan, Kedah Darul Aman, Malaysia; (J) Tioman Island, Pahang Darul Makmur; Peninsular Malaysia; Pangkor Island, Perak; Malaysia; (K) Sari Ringgung, Lampung, Indonesia; (L) Larak Island, Persian Gulf, Iran; (M) Tabarka, Tunisia; and (N) the Antarctic.

\subsection{Culturable Microorganisms Associated with Sea Cucumbers}

The sea cucumbers used for the isolation of culturable microorganisms belong to five genera (Holothuria, Cucumaria, Stichopus, Apostichopus, and Eupentacta) in four families (Holothuriidae, Stichopodidae, Cucumariidae, and Sclerodactylidae) (Table 1). The dominant species is Apostichopus japonicus, which accounts for about $41 \%$ of the total sea cucumber population. In second place, Holothuria leucospilota accounts for about $27 \%$ of the total sea cucumber population (Table S1).

In studies on microorganisms associated with sea cucumbers, samples are primarily obtained from the following body parts: the body wall [22,23], body surface [18,21,24-29], inner body tissue [30], coelomic fluid [24,31], stomach [30], intestines [4,6,17,19,25,32-35], brown gastrointestinal tissue [30], and feces [20,22].

Sea cucumbers harbor a rich and diverse assortment of microorganisms. A variety of microorganisms, including bacteria and fungi, have been isolated from sea cucumbers. Most of the isolation conditions (medium, temperature, and aeration) are common. There are some papers on the diversity of culturable bacteria associated with sea cucumbers, which plays a very important role in understanding the digestion and diseases of sea cucumbers $[4,6,17,25,33]$. Because marine-derived fungi had shown potential to synthesize 
pharmaceutical compounds with bioactivities, researchers usually directly isolate fungi associated with sea cucumbers for the separation of active natural products $[21,28,29]$, except one paper about the diversity and bioactivity of fungi associated with sea cucumbers [22].

\subsubsection{Bacteria}

To date, 78 genera belonging to 47 families in four phyla have been cultured from sea cucumbers (Table 2) $[4,6,17-19,23-26,30-34]$. The phylum Proteobacteria was represented by 34 genera, 23 genera belong to the phylum Actinobacteria, 13 genera belong to the phylum Firmicutes, and only eight genera were from the phylum Bacteroidetes. The bacteria isolated from sea cucumbers are mainly the genus Bacillus, followed by Vibrio, and Pseudoalteromona (Table S1).

Bacteria have been isolated from seven species in three genera of sea cucumbers: Apostichopus japonicus, Holothuria atra, Holothuria edulis, Holothuria leucospilota, Stichopus badionotus, Stichopus chloronotus, and Stichopus vastus [4,6,17-19,23-26,30-34]. A. japonicus displayed a high bacterial diversity, and 54 bacterial genera were isolated from this species. Thirty-six genera were isolated from $\mathrm{H}$. leucospilota, and fifteen genera were isolated from S. vastus. Two, one, six, and three genera of bacteria were isolated from H. atra, H. edulis, $S$. badionotus, and S. chloronotus, respectively (Table 1 and Table S1).

\subsubsection{Fungi}

Sea-cucumber-associated fungi belong to 29 genera in 24 families (Table 2). All of them are in the phylum Ascomycota [20-22,27-29,35-45]. The dominant genus was Aspergillus, followed by Penicillium (Table S1).

Fungi were isolated from six species in five genera of sea cucumbers: A. japonicus, Cucumaria japonica, Eupentacta fraudatrix, Holothuria nobilis, Holothuria poli, and Stichopus japonicus $[20,22,29,35-42]$. Among them, the greatest number of fungal species was isolated from $H$. poli, with 16 genera. Thirteen genera were isolated from E. fraudatrix, and twelve genera were isolated from A. japonicus. Two, three, and one genera of fungi were isolated from the sea cucumbers C. japonica, H. nobilis, and S. japonicus, respectively (Table 1 and Table S1).

Table 1. Sea cucumbers used for the isolation of culturable microorganisms.

\begin{tabular}{|c|c|c|c|c|c|}
\hline \multicolumn{3}{|c|}{ Sea Cucumbers } & \multicolumn{2}{|c|}{ Microorganism Genera } & \multirow{2}{*}{ References } \\
\hline Family & Genus & Species & Bacteria & Fungi & \\
\hline Cucumariidae & Cucumaria & japonica & 0 & 2 & {$[20,36]$} \\
\hline \multirow[t]{5}{*}{ Holothuriidae } & Holothuria & atra & 2 & 0 & {$[30]$} \\
\hline & & edulis & 1 & 0 & [18] \\
\hline & & leucospilota & 36 & 0 & {$[4,19,25,31]$} \\
\hline & & nobilis & 0 & 3 & {$[35,37,38]$} \\
\hline & & poli & 0 & 16 & {$[22]$} \\
\hline Sclerodactylidae & Eupentacta & fraudatrix & 0 & 13 & {$[20,21]$} \\
\hline \multirow[t]{5}{*}{ Stichopodidae } & Apostichopus & japonicus & 54 & 12 & {$[6,17,20,23,24,29,32-34,39,40]$} \\
\hline & Stichopus & badionotus & 6 & 0 & [26] \\
\hline & & chloronotus & 3 & 0 & {$[31]$} \\
\hline & & japonicus & 0 & 1 & {$[41,42]$} \\
\hline & & vastus & 15 & 0 & [25] \\
\hline
\end{tabular}


Table 2. Culturable microorganisms associated with sea cucumbers.

\begin{tabular}{|c|c|c|c|c|c|}
\hline Kingdom & Phylum & Class & Family & Genus & References \\
\hline \multirow[t]{41}{*}{ Bacteria } & Actinobacteria & Acidimicrobiia & Iamiaceae & Iamia & [18] \\
\hline & & Actinomycetia & Brevibacteriaceae & Brevibacterium & {$[23,25]$} \\
\hline & & & Corynebacteriaceae & Corynebacterium & [25] \\
\hline & & & Dermabacteraceae & Brachybacterium & [6] \\
\hline & & & Dermacoccaceae & Dermacoccus & [25] \\
\hline & & & Dietziaceae & Dietzia & [25] \\
\hline & & & Gordoniaceae & Williamsia & [24] \\
\hline & & & Intrasporangiaceae & Janibacter & [25] \\
\hline & & & Kytococcaceae & Kytococcus & {$[25,31]$} \\
\hline & & & Microbacteriaceae & Microbacterium & {$[6,32]$} \\
\hline & & & Micrococcaceae & Glutamicibacter & {$[6,25]$} \\
\hline & & & & Kocuria & [25] \\
\hline & & & & Micrococcus & {$[4,6,24,25,31,33]$} \\
\hline & & & & Rothia & {$[24,25,31]$} \\
\hline & & & Nocardioidaceae & Nocardioides & [25] \\
\hline & & & Nocardiopsaceae & Nocardiopsis & {$[4,6,17]$} \\
\hline & & & Oerskoviaceae & Paraoerskovia & [4] \\
\hline & & & Ornithinimicrobiaceae & Ornithinimicrobium & [25] \\
\hline & & & & Serinicoccus & [25] \\
\hline & & & Promicromonosporaceae & Cellulosimicrobium & {$[6,25]$} \\
\hline & & & & Isoptericola & [25] \\
\hline & & & Propionibacteriaceae & Pseudopropionibacterium & [25] \\
\hline & & & Streptomycetaceae & Streptomyces & {$[6,17,19,25]$} \\
\hline & Bacteroidetes & Cytophagia & Cytophagaceae & Cytophaga & [24] \\
\hline & & Flavobacteriia & Flavobacteriaceae & Flavobacterium & [33] \\
\hline & & & & Lacinutrix & [24] \\
\hline & & & & Maribacter & [24] \\
\hline & & & & Psychroserpens & [24] \\
\hline & & & & Ulvibacter & [24] \\
\hline & & & & Winogradskyella & [24] \\
\hline & & & & Zobellia & [24] \\
\hline & Firmicutes & Bacilli & Bacillaceae & Bacillus & {$[4,6,17,24,25,30-33]$} \\
\hline & & & & Geomicrobium & {$[4,17]$} \\
\hline & & & & Gracilibacillus & {$[4,17]$} \\
\hline & & & & Halobacillus & {$[4,6,17]$} \\
\hline & & & & Halolactibacillus & [17] \\
\hline & & & & Oceanobacillus & {$[4,17]$} \\
\hline & & & & Salsuginibacillus & [17] \\
\hline & & & & Virgibacillus & {$[4,6,17]$} \\
\hline & & & Planococcaceae & Lysinibacillus & [17] \\
\hline & & & & Planococcus & [26] \\
\hline
\end{tabular}


Table 2. Cont.

\begin{tabular}{|c|c|c|c|c|c|}
\hline Kingdom & Phylum & Class & Family & Genus & References \\
\hline & & & & Sporosarcina & {$[4,17]$} \\
\hline & & & Staphylococcaceae & Staphylococcus & {$[4,25]$} \\
\hline & & & Unidentified & Exiguobacterium & {$[26,31]$} \\
\hline & Proteobacteria & Alphaproteobacteria & Ahrensiaceae & Ahrensia & {$[24]$} \\
\hline & & & Erythrobacteraceae & Erythrobacter & [25] \\
\hline & & & Rhizobiaceae & Agrobacterium & {$[24]$} \\
\hline & & & Rhodobacteraceae & Epibacterium & [25] \\
\hline & & & & Marinosulfonomonas & [24] \\
\hline & & & & Octadecabacter & [24] \\
\hline & & & & Paracoccus & [25] \\
\hline & & & & Roseobacter & [24] \\
\hline & & & & Ruegeria & [4] \\
\hline & & & Sphingomonadaceae & Sphingomonas & {$[24,26]$} \\
\hline & & & Stappiaceae & Pseudovibrio & [17] \\
\hline & & Betaproteobacteria & Comamonadaceae & Acidovorax & [24] \\
\hline & & Gammaproteobacteria & Aeromonadaceae & Aeromonas & [33] \\
\hline & & & & Oceanisphaera & {$[32]$} \\
\hline & & & Alteromonadaceae & Alteromonas & [24] \\
\hline & & & Colwelliaceae & Colwellia & [24] \\
\hline & & & Enterobacteriaceae & Enterobacter & [33] \\
\hline & & & & Klebsiella & [30] \\
\hline & & & Erwiniaceae & Pantoea & [25] \\
\hline & & & Ferrimonadaceae & Ferrimonas & [17] \\
\hline & & & Halomonadaceae & Halomonas & {$[4,33]$} \\
\hline & & & Idiomarinaceae & Pseudidiomarina & [32] \\
\hline & & & Lysobacteraceae & Stenotrophomonas & [31] \\
\hline & & & Moraxellaceae & Acinetobacter & {$[25,32]$} \\
\hline & & & & Psychrobacter & [24-26] \\
\hline & & & Oceanospirillaceae & Marinobacterium & [32] \\
\hline & & & & Marinomonas & {$[24,32]$} \\
\hline & & & Pseudoalteromonadaceae & Pseudoalteromonas & {$[4,17,24,26,32-34]$} \\
\hline & & & Pseudomonadaceae & Pseudomonas & {$[6,17,24,25,31-33]$} \\
\hline & & & Psychromonadaceae & Psychromonas & [24] \\
\hline & & & Shewanellaceae & Shewanella & {$[4,6,24,32]$} \\
\hline & & & Vibrionaceae & Aliivibrio & [24] \\
\hline & & & & Photobacterium & [4] \\
\hline & & & & Vibrio & {$[4,6,24-26,31-33]$} \\
\hline \multirow[t]{4}{*}{ Fungi } & Ascomycota & Dothideomycetes & Cladosporiaceae & Cladosporium & {$[20,22]$} \\
\hline & & & Didymellaceae & Epicoccum & {$[20,40,43]$} \\
\hline & & & Pleosporaceae & Alternaria & {$[20,22,27,28]$} \\
\hline & & & & Ulocladium & [20] \\
\hline
\end{tabular}


Table 2. Cont.

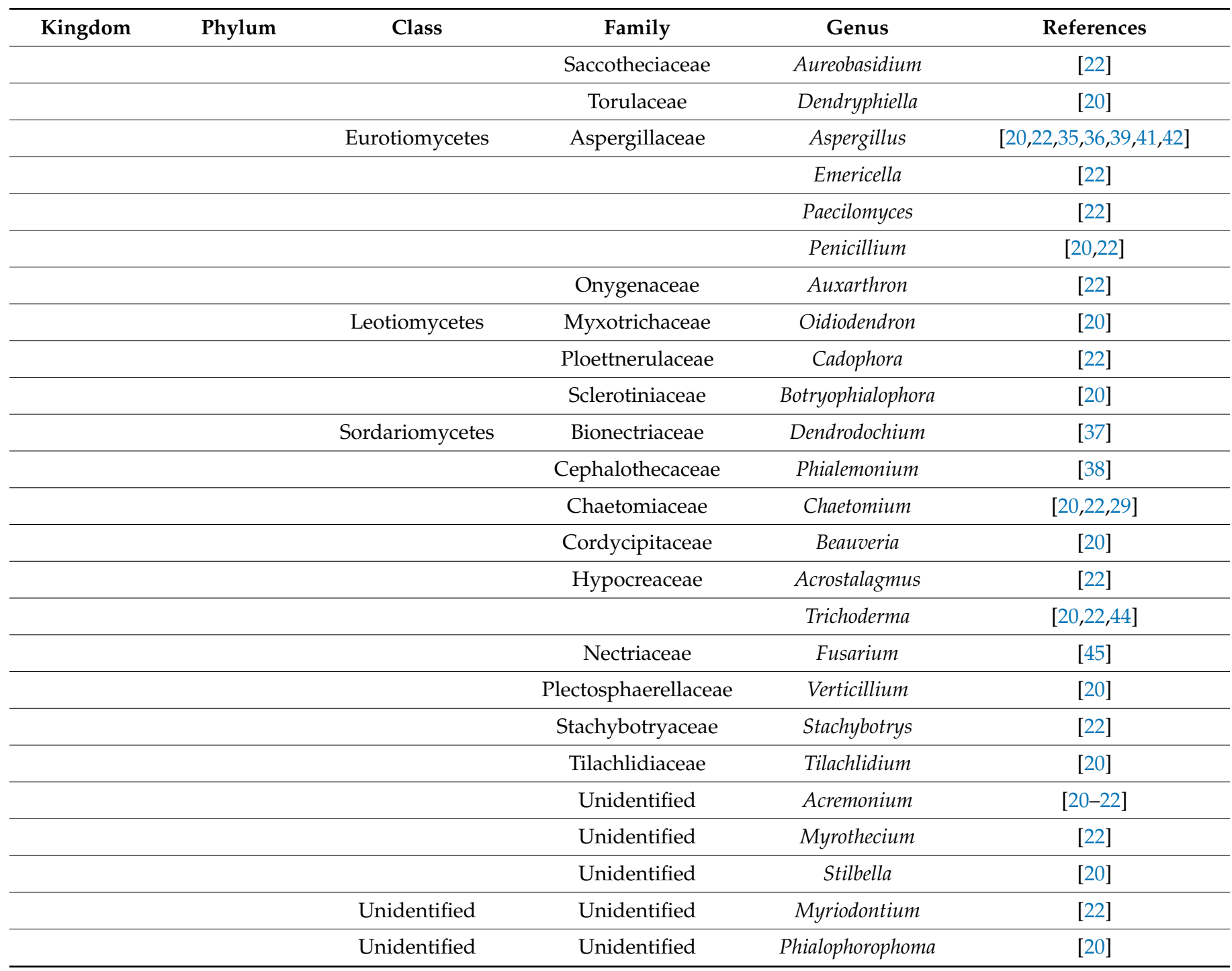

\section{Structures and Bioactivities of Natural Products}

To date, 145 natural products have been isolated from sea-cucumber-associated microorganisms (Figure 2). These compounds include polyketides, alkaloids, and terpenoids, among others. These natural products have diverse properties, such as cytotoxic [37,39,45], antimicrobial [44], enzyme-inhibiting [46], and antiangiogenic activities [47].

\subsection{Polyketides}

Polyketides are a class of secondary metabolites that are produced by bacteria, fungi, actinobacteria, and plants [48,49]. They include polyphenols, macrolides, polyenes, anthraquinones, enediynes, and other compounds [50,51]. Polyketides have diverse bioactive properties, including antibiotic, antifungal, immunosuppressant, antiparasitic, cholesterollowering, and antitumoral activities [50,52].

The polyketones territrem A (1), territrem B (2), dihydrogeodin (3), emodin (4), questin (5), and 1-(2,4-dihydroxyphenyl)-ethanone (6) were isolated from the marine fungus $A s$ pergillus terreus, associated with the sea cucumber A. japonicus, collected from Zhifu Island in Yantai, China [39]. Compounds 4 and 5 are common quinone compounds, and compound 4 has cytotoxic effects on human oral epithelial cancer cells (KB) and multidrug-resistant cells (KBv200), with $\mathrm{IC}_{50}$ values of 32.97 and $16.15 \mu \mathrm{g} / \mathrm{mL}$, respectively [39]. Compound 4 was also isolated from sea-cucumber-derived fungus Trichoderma sp., and it showed weak 
inhibitory effects against Pseudomonas putida, with a minimum inhibitory concentration (MIC) of $25 \mu \mathrm{M}$ [44]. Compound 5 has weak cytotoxicity in $\mathrm{KB}$ and KBv200 cells, with $\mathrm{IC}_{50}$ values $>50 \mu \mathrm{g} / \mathrm{mL}$ [39].

Three additional compounds, 1-hydroxyl-3-methylanthracene-9,10-dione (7), chrysophanol (8), and sterigmatocystin (9), are secondary metabolites of the fungus Alternaria sp., isolated from sea cucumber in the sea surrounding Zhifu Island in Yantai, China [28]. Compound $\mathbf{8}$ was also isolated from a sea-cucumber-associated fungus Trichoderma sp. and showed weak inhibitory effects against Vibrio parahaemolyticus, with an MIC value of $25 \mu \mathrm{M}$ [44].

The anthraquinone compounds coniothyrinone A (10) and lentisone (11) were isolated from the fungus Trichoderma sp. associated with a sea cucumber that was collected from Chengshantou Island in the Yellow Sea in Weihai City, China [44]. Compounds 10 and 11 were isolated for the first time from fungi of the genus Trichoderma, and they had weak antiangiogenicc activity. Compound $\mathbf{1 0}$ showed pronounced antibacterial activity against three common marine pathogens, Vibrio parahaemolyticus, Vibrio anguillarum, and Pseudomonas putida, and the MIC values were $6.25,1.56$, and $3.13 \mu \mathrm{M}$, respectively. Compound 11 showed inhibitory effect against $V$. parahaemolyticus, $V$. anguillarum, and $P$. putida, with MIC values of $12.5,1.56$, and $6.25 \mu \mathrm{M}$, respectively [44].

Six compounds, javanicin (12), norjavanicin (13), fusarubin (14), terrain (15), sclerin (16), and 5-hydroxy-7-methoxy-3-methyl-2-(2-oxopropyl) naphthalene-1,4-dione (17), were isolated from the sea-cucumber-associated fungus Fusarium sp. from the Yantai Sea, China [45]. Compounds $\mathbf{1 2 - 1 4}$ showed moderate cytotoxicity in $\mathrm{KB}$ cells, with $\mathrm{IC}_{50}$ values of $2.90,10.6$, and $9.61 \mathrm{~g} / \mathrm{mL}$, respectively, and they also showed moderate cytotoxic effects in KBv200 cells, with $\mathrm{IC}_{50}$ values of $5.91,12.12$, and $6.74 \mathrm{~g} / \mathrm{mL}$, respectively [45].

Four new polyhydroxy cyclohexanol analogues, named dendrodochol A-D (18-21), were isolated from the fungus Dendrodochium sp. associated with the sea cucumber $H$. nobilis, which was collected from the South China Sea [53]. Compounds $\mathbf{1 8}$ and 20 showed modest antifungal activity against Candida strains, Cryptococcus neoformans, and Trichophyton rubrum $\left(\mathrm{MIC}_{80}=8-16 \mu \mathrm{g} / \mathrm{mL}\right.$ ) in an in vitro bioassay [53]. Additionally, thirteen new 12-membered macrolides, dendrodolides A-M (22-34), were isolated from the fungus Dendrodochium sp. associated with the sea cucumber H. nobilis [37]. Compounds 22-25, 29, 30, and 32 showed cytotoxic effects on SMMC-7721 tumor cells, with IC 50 values of 19.2, 24.8, 18.0, 15.5, 21.8, 14.7, and $21.1 \mu \mathrm{g} / \mathrm{mL}$, respectively [37]. Compounds 24, 26, 28, 30, 32, and 33 had cytotoxic effects on HCT116 tumor cells, with $\mathrm{IC}_{50}$ values of 13.8, 5.7, 9.8, 11.4, 15.9 , and $26.5 \mu \mathrm{g} / \mathrm{mL}$, respectively [37].

Aspergillolide (35), a newly discovered 12-membered macrolide, was isolated from the fungus Aspergillus sp. S-3-75, associated with the sea cucumber H. nobilis that was collected from the Antarctic [35].

Azaphilone compounds are fungal polyketide pigments produced by a variety of ascomycetes and basidiomycetes [54]. Four previously known azaphilones, chaetoviridin A (36), chaetoviridin E (37), chaetoviridin B (38), and chaetomugilin A (39), and a known cochliodinol (40), were produced by the fungus Chaetomium globosum, associated with the sea cucumber $A$. japonicus, which was collected from Chengshantou Island, Weihai, China [29].

\subsection{Alkaloids}

Alkaloids have been identified as a class of nitrogenous organic compounds derived from plants $[55,56]$; although they are most commonly found in plants, alkaloids can also be isolated from marine organisms and marine microorganisms [57,58].

Chaetoglobosins, which are a large class of secondary metabolites that are cytochalasin alkaloids, have been isolated mainly from the fungus Chaetomium globosum [59]. Three previously known chaetoglobosins, chaetoglobosin Fex (41), G (42), and B (43), and one new chaetoglobosin, cytoglobosin X (44), were isolated from the fungus Chaetomium globosum, associated with the sea cucumber $A$. japonicus, on Chengshantou Island, China [29]. Com- 
pound $\mathbf{4 3}$ has some inhibitory effects against Staphylococcus aureus and methicillin-resistant Staphylococcus aureus (MRSA), with MIC values of 47.3 and $94.6 \mu \mathrm{M}$, respectively, and weak activity against Candida albicans SC5314, Candida albicans 17\#, Pseudomonas aeruginosa, and Bacillus Calmette-Guérin (BCG), with MIC values $>100 \mu \mathrm{g} / \mathrm{mL}$ for all organisms [29].

Nineteen compounds were isolated from the fungus Aspergillus fumigatus, associated with the sea cucumber S. japonicus, collected near Lingshan Island, Qingdao, China [33]. Among these 19 compounds are seven new prenylated indole diketopiperazine alkaloids, including compound 45, three spirotryprostatins (C-E) (46-48), two derivatives of fumitremorgin B (49 and 50), and 13-oxoverruculogen (51), along with 12 known compounds, including spirotryprostatin A (52), 13-oxofumitremorgin B (53), fumitremorgin B (54), verruculogen (55), 3- $\beta$ hydroxy cyclo-L-tryptophyl-L-proline (56), cyclo-L-tryptophyl-Lproline (57), tryprostatin B (58), tryprostatin A (59), N-prenyl-cyclo-L-tryptophyl-L-proline (60), fumitremorgin $C$ (61), 12,13-dihydroxyfumitremorgin $C$ (62), and cyclotryprostatin A (63) [41]. Compound 45 showed weak cytotoxicity in HL-60 cells, with an IC 50 value of $125.3 \mu \mathrm{M}$. Compounds $\mathbf{4 6}-\mathbf{5 1}$ exhibited some cytotoxicity in MOLT-4 cells, HL-60 cells, A-549 cells, and BEL-7402 cells. Compound 48 showed higher activity in MOLT-4 and A-549 cells than the others, with an $\mathrm{IC}_{50}$ value of $3.1 \mu \mathrm{M}$ for both cell types. Compound 49 showed higher activity in BEL-7402 cells than the others, with an $\mathrm{IC}_{50}$ value of $7.0 \mu \mathrm{M}$. Compound 51 showed higher activity in HL-60 cells than the others, with an $\mathrm{IC}_{50}$ value of $1.9 \mu \mathrm{M}$ [41]. Compound 53 was also isolated from the fungus Aspergillus sp., associated with the sea cucumber $S$. japonicus, collected from Lingshan Island, Qingdao, China [42]. Two new compounds, pseurotin $A_{1}(64)$ and $A_{2}$ (65), as well as pseurotin $A(66)$ were also isolated from the fungus Aspergillus fumigatus, associated with the sea cucumber $S$. japonicus. Compound 65 exhibited slight cytotoxicity in A549 and HL-60 cells, with $\mathrm{IC}_{50}$ values of 48.0 and $70.8 \mu \mathrm{mol} / \mathrm{L}$, respectively, and compound 66 showed slight cytotoxicity in HL-60 cells, with an $\mathrm{IC}_{50}$ value of $67.0 \mu \mathrm{mol} / \mathrm{L}$ [60].

\subsection{Terpenoids}

Terpenoids, which are widely found in nature and in numerous species, have various structures and are divided into monoterpenes $\left(C_{10}\right)$, sesquiterpenes $\left(C_{15}\right)$, diterpenes $\left(C_{20}\right)$, and sesterterpenes $\left(\mathrm{C}_{25}\right)$ [61]. Although most known terpenoids have been isolated from plants [62], they are also produced by marine microorganisms [63].

Three new pimarane diterpenes, aspergilone A (67) and compounds 68 and 69, one new isopimarane diterpene (70), and four known compounds, diaporthin B (71), diaporthein B (72), 11-deoxydiaporthein A (73), and isopimara-8(14),15-diene (74), were obtained from the fungus Epicoccum sp., associated with the sea cucumber A. japonicus, which was collected from Yantai, Shandong Province, China [40,64,65]. Compounds 67, 68, and 71 exhibited cytotoxicity in $\mathrm{KB}$ cells, with $\mathrm{IC}_{50}$ values of $3.51,20.74$, and $3.86 \mu \mathrm{g} / \mathrm{mL}$, respectively, and in KBv200 cells, with $\mathrm{IC}_{50}$ values of 2.34, 14.47, and $6.52 \mu \mathrm{g} / \mathrm{mL}$, respectively [40]. Compounds $\mathbf{7 0}$ and $\mathbf{7 3}$ exhibited effective inhibitory activities against $\alpha$-glucosidase, with $\mathrm{IC}_{50}$ values of 4.6 and $11.9 \mu \mathrm{M}$, respectively [65].

The fungus Aspergillus sp. H30, derived from the sea cucumber Cucumaria japonica, which was collected from the South China Sea, produced a meroterpenoid called chevalone B (75) that exhibited weak antibacterial activity [36].

Terpene glycosides are a group of natural products with a triterpene or sterol core, and marine diterpene glycosides (MDGs) are a subset of terpene glycosides [66]. Thirty-one new diterpene glycosides, including virescenosides $M-R$ (76-81), $R_{1}-R_{3}(\mathbf{8 2}-84), S-X(85-90), Z(91)$, and $Z_{4}-Z_{18}(\mathbf{9 2}-106)$, and three known diterpenic glycosides, virescenosides $A(\mathbf{1 0 7}), B(108)$, and $C(\mathbf{1 0 9})$, together with three known analogues, virescenoside $F(\mathbf{1 1 0}), G(\mathbf{1 1 1})$, a lactone of virescenoside $G$ (112), and the aglycon of virescenoside $A$ (113), were isolated from the fungus Acremonium striatisporum KMM 4401, associated with the sea cucumber Eupentacta fraudatrix, which was collected from Kitovoe Rebro Bay in the Sea of Japan [21,46,67-71]. Compounds 76, 77, 79, and 107-109 showed cytotoxic effects on developing eggs of the sea urchin Strongylo-

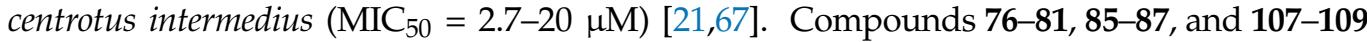


exhibited cytotoxic activities against Ehrlich carcinoma tumor cells $\left(\mathrm{IC}_{50}=10-100 \mu \mathrm{M}\right)$ in vitro $[21,67,68]$. Compounds $\mathbf{8 1}$ and $\mathbf{8 5 - 8 7}$ showed weak cytotoxic effects on developing eggs of the sea urchin S. intermedius ( $\left.\mathrm{IC}_{50}=100-150 \mu \mathrm{M}\right)$ [68]. At a concentration of $100 \mathrm{mg} / \mathrm{mL}$, compounds 82-84 and 91 inhibited esterase activity by 56\%, 58\%, 36\%, and 40\%, respectively [46]. The aglycon 113 inhibited urease activity, with an $\mathrm{IC}_{50}$ value of $138.8 \mu \mathrm{M}$ [71]. Compounds 97, 98, 100, 101, 104, and 110-113, at $10 \mu \mathrm{M}$, downregulated reactive oxygen species (ROS) production in lipopolysaccharide (LPS)-stimulated macrophages [71]. At $1 \mu \mathrm{M}$, compounds $\mathbf{9 8}$ and 101 induced moderate downregulation of NO production in LPSstimulated macrophages [71].

\subsection{Other Types of Compounds Isolated from Sea-Cucumber-Associated Microorganisms}

Other secondary metabolites, including cyclo-(L-Pro-L-Phe) (114), cyclo-(L-Pro-L-Met) (115), cyclo-(L-Pro-L-Tyr) (116), cyclo-(L-Pro-L-Val) (117), cyclo-(L-Pro-L-Pro) (118), cyclo-(LVal-L-Gly) (119), and cyclo-(L-Pro-L-Leu) (120), have been isolated from the actinomycete Brevibacterium sp., associated with the sea cucumber A. japonicus [23].

Four compounds, 5-methyl-6-hydroxy-8-methyoxy-3-methylisochroman (121), peroxyergosterol (122), succinic acid (123), and 8-hydroxy-3-methylisochroman-1-one (124), were isolated from the fungus Epicoccum spp., associated with sea cucumber collected in the Yellow Sea, China [43]. Compound 121 is a pheromone [43] that was also isolated from the fungus Alternaria sp., associated with the sea cucumber collected from the Yellow Sea in Weihai, China [27]. The fungus Alternaria sp., associated with sea cucumber, also produced a new benzofuran derivative, 4-acetyl-5-hydroxy-3,6,7-trimethylbenzofuran-2(3H)-one (125), and a known compound, 2-carboxy-3-(2-hydroxypropanyl) phenol (126) [27].

Two depsidones, emeguisin A (127) and aspergillusidone C (128), were isolated from the fungus Phialemonium sp., associated with the sea cucumber H. nobilis, collected in South China [38].

Three compounds, (+)-butyrolactone IV (129), butyrolactone I (130), and terrelactone A (131), were isolated from the fungus Aspergillus terreus, associated with the sea cucumber A. japonicus, collected from the Yellow Sea in China [47]. Compounds 129 and 130 showed moderate antiangiogenic activity when evaluated using a zebrafish assay. The inhibition ratio of compound 129, at a concentration of $100 \mu \mathrm{g} / \mathrm{mL}$, was $43.4 \%$ and that of compound 130, at a concentration of $10 \mu \mathrm{g} / \mathrm{mL}$, was $28.7 \%$ [47].

Nine known compounds, 2,4-dihydroxy-6-methylaceto-phenone (132), pannorin (133), 2-hydroxy-4-(3-hydroxy-5-methylphenoxy)-6-methylbenzoic acid (134), 3,3'-dihydroxy5,5'-dimethyldiphenyl ether (135), aloesone (136), aloesol (137), acremolin (138), cyclo-(LTrp-L-Phe) (139), and cyclo-(L-Trp-L-Leu) (140), were isolated from the fungus Aspergillus sp. S-3-75, associated with the sea cucumber H. nobilis, which was collected from the Antarctic [35].

Cerebroside (141) was isolated from the fungus Alternaria sp., associated with sea cucumber from the sea near Zhifu Island in Yantai, China [28].

Three known compounds, streptodepsipeptide P11B (142), streptodepsipeptide P11A (143), and valinomycin (144), and one novel valinomycin analogue, streptodepsipeptide SV21 (145), were produced by the actinobacteria Streptomyces sp. SV 21, isolated from the sea cucumber $S$. vastus in Lampung, Indonesia [72]. Compounds 142-145 exhibited antifungal activity against Mucor hiemalis, with MIC values of $16.6,8.3,2.1$, and $16.6 \mu \mathrm{g} / \mathrm{mL}$, respectively. These four compounds also exhibited antifungal activity against Ruegeria glutinis, with MIC values of 33.3, 8.3,4.2, and $16.6 \mu \mathrm{g} / \mathrm{mL}$, respectively. Compounds 144 and 145 showed activities against the Gram-positive bacterium Staphylococcus aureus, with MIC values of 4.2 and $16.6 \mu \mathrm{g} / \mathrm{mL}$, respectively. Compound 145 showed activity against the Gram-positive bacterium Bacillus subtilis, with an MIC value of $33.3 \mu \mathrm{g} / \mathrm{mL}$. Compounds 143-145 showed pronounced antiinfectivity effects against hepatitis $C$ virus (HCV). Compound 142 showed weak antiinfectivity effects against HCV [72]. 


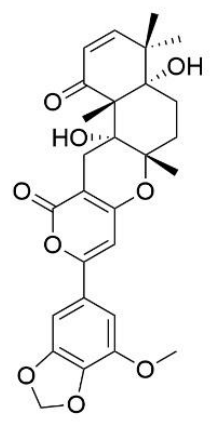

1<smiles>COc1cc(O)cc2c1C(=O)c1c(O)cc(C)cc1C2=O</smiles><smiles>COc1cc2c(c3oc4cccc(O)c4c(=O)c13)[C@@H]1C=COC1O2</smiles>

9<smiles>COc1cc(O)c2c(c1O)C(=O)C1=C(COC(C)(O)C1)C2=O</smiles>

14

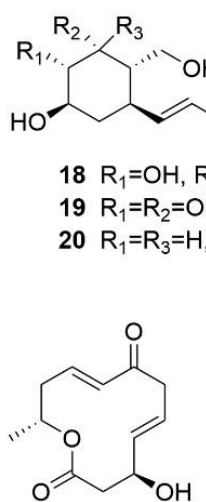

26<smiles>COc1cc(-c2cc3c(c(=O)o2)C[C@H]2[C@@](O)(CCC4(C)C(=O)C=CC(C)(C)[C@]24O)O3)cc(OC)c1OC</smiles>

2<smiles>COC(=O)c1cc(O)cc(OC)c1C(=O)c1c(O)c(Cl)c(C)c(Cl)c1O</smiles><smiles>Cc1cc(O)c2c(c1)C(=O)c1ccccc1C2=O</smiles><smiles>CC(=O)c1ccc(O)cc1O</smiles><smiles>Cc1cc(O)c2c(c1)C(=O)c1cccc(O)c1C2=O</smiles><smiles>Cc1cc(O)c2c(c1)[C@H](O)[C@@H]1C=C[C@@H](O)[C@H](O)[C@H]1C2=O</smiles>

10<smiles>Cc1cc(O)c2c(c1)C(=O)C1=C(C2)C(O)[C@H](O)[C@H](O)C1</smiles>

11<smiles>[R]c1c(O)c2c(c(O)c1CC(C)=O)C(=O)C(OC)=CC2=O</smiles>

12: $\mathrm{R}=\mathrm{CH}_{3}$

13: $\mathrm{R}=\mathrm{H}$

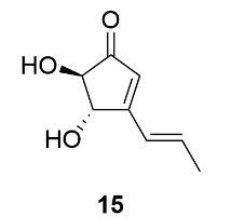<smiles>Cc1c(C)c(O)c2c(c1C)C(C)C(=O)OC2=O</smiles>

16<smiles>COc1cc(O)c2c(c1)C(=O)C(CC(C)=O)=C(C)C2=O</smiles>

17<smiles>[R2]C1C(O)CC(/C=C/C=C/C=C/C)C(CO)C1([R])[R]</smiles>

$18 \mathrm{R}_{1}=\mathrm{OH}, \mathrm{R}_{2}, \mathrm{R}_{3}=\mathrm{O}$

$19 \mathrm{R}_{1}=\mathrm{R}_{2}=\mathrm{OH}, \mathrm{R}_{3}=\mathrm{H}$<smiles>CC(O)/C=C/C=C/[C@H]1OC[C@H]2[C@@H](O)[C@H](O)[C@@H](O)C[C@@]21O</smiles>

21<smiles>C[C@H]1/C=C\[C@@H](O)C/C=C/[C@H](O)CC(=O)O1</smiles>

27<smiles>C[C@H]1/C=C\[C@@H](O)C/C=C/[C@H](O)CC(=O)O1</smiles>

28<smiles>[R]OC(CC(=O)CC=CC(O)CC(=O)O)C[C@@H](C)OC</smiles>

$22 \mathrm{R}=\mathrm{Me}$ $24 \mathrm{R}=\mathrm{H}$

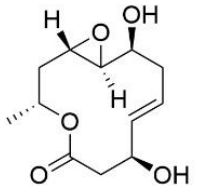

29<smiles>[R7]C1CC(=O)C/C=C/[C@H](O)CC(=O)O[C@@H](C)C1</smiles>

$23 \mathrm{R}=\mathrm{Me}$ $25 \mathrm{R}=\mathrm{H}$

Figure 2. Cont. 
<smiles>C[C@H]1CCCC(O)C/C=C/C(O)CC(=O)O1</smiles>

31<smiles>C[C@H]1CC(O)CC(O)C/C=C/C(O)CC(=O)O1</smiles>

32<smiles>C[C@H]1CCCC(=O)CCC[C@@H](O)CC(=O)O1</smiles>

33<smiles>CCC(CC(=O)/C=C/C[C@@H](C)OC(=O)CC(O)CC(=O)O)OC</smiles>

34<smiles>C[C@H]1CCC[C@@H](O)CC[C@@H](O)CCC(=O)O1</smiles>

35<smiles>CCC(C)/C=C/C1=CC2=C(Cl)C(=O)C3(C)OC(=O)C(C(=O)C(C)C(C)O)=C3C2=CO1</smiles>

36

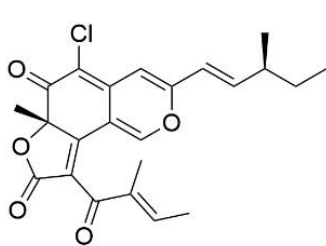

37

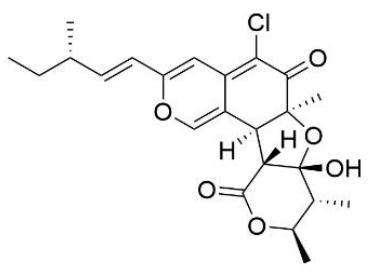

38

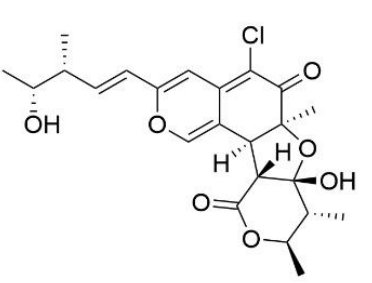

39

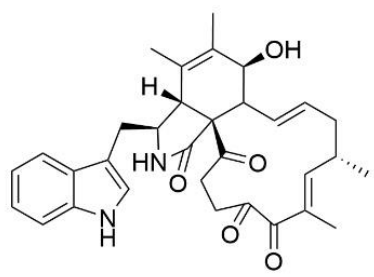

42

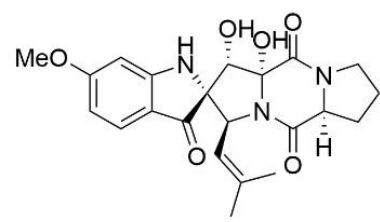

45

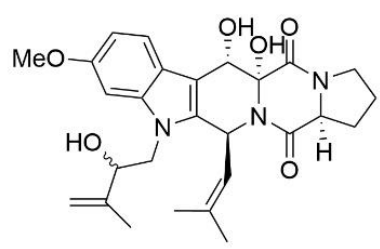

49、 50<smiles>CC(C)=CCc1ccc2[nH]cc(C3=C(O)C(=O)C(c4c[nH]c5ccccc45)=C(O)C3=O)c2c1</smiles>

40

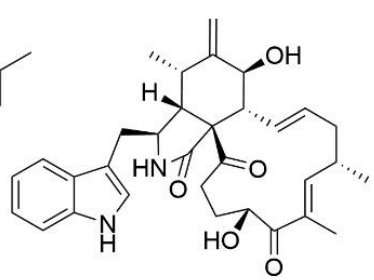

41

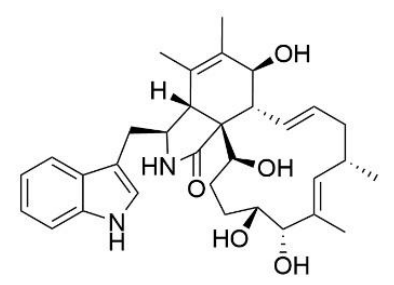

44<smiles>COc1ccc2c(c1)NC(=O)[C@]21CC2C(=O)N3CCC[C@H]3C(=O)N2C1C=C(C)C</smiles>

52

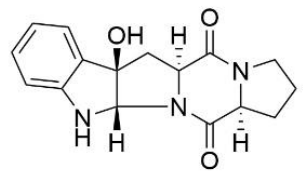

$48 \mathrm{R}_{1}=\varlimsup_{\mathrm{HOO}} \mathrm{R}_{2}=\mathrm{H}$

56

Figure 2. Cont. 


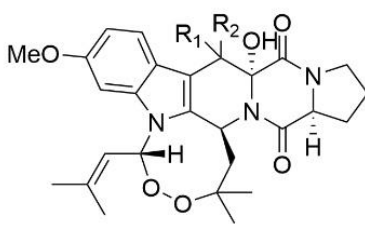

$51 \quad \mathrm{R}_{1}=\mathrm{R}_{2}=\mathrm{O}$

$55 \quad \mathrm{R}_{1}=\beta-\mathrm{H} \quad \mathrm{R}_{2}=\alpha-\mathrm{OH}$

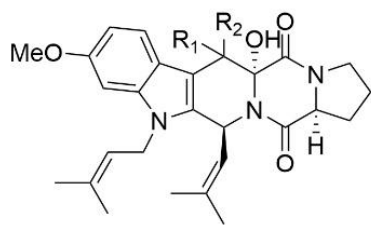

$53 \quad \mathrm{R}_{1}=\mathrm{R}_{2}=\mathrm{O}$

$54 \quad \mathrm{R}_{1}=\beta-\mathrm{H} \quad \mathrm{R}_{2}=\alpha-\mathrm{OH}$

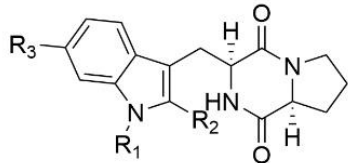

$57 \quad \mathrm{R}_{1}=\mathrm{R}_{2}=\mathrm{R}_{3}=\mathrm{H}$

$58 \quad \mathrm{R}_{1}=\mathrm{R}_{3}=\mathrm{H} \quad \mathrm{R}_{2}=\longrightarrow$

$59 \quad \mathrm{R}_{1}=\mathrm{H} \quad \mathrm{R}_{3}=\mathrm{OMe} \quad \mathrm{R}_{2}=\square \longrightarrow$

$60 \quad \mathrm{R}_{2}=\mathrm{R}_{3}=\mathrm{H} \quad \mathrm{R}_{1}=\longrightarrow$

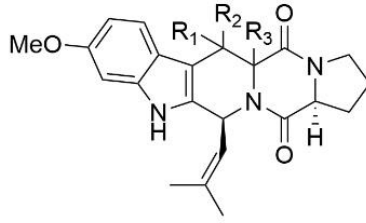

$61 \quad \mathrm{R}_{1}=\mathrm{R}_{2}=\mathrm{H} \quad \mathrm{R}_{3}=\beta-\mathrm{H}$

$62 \quad \mathrm{R}_{1}=\beta-\mathrm{H} \quad \mathrm{R}_{2}=\alpha-\mathrm{OH} \quad \mathrm{R}_{3}=\alpha-\mathrm{OH}$

$63 \quad \mathrm{R}_{1}=\beta-\mathrm{H} \quad \mathrm{R}_{2}=\alpha-\mathrm{OH} \quad \mathrm{R}_{3}=\beta-\mathrm{OH}$

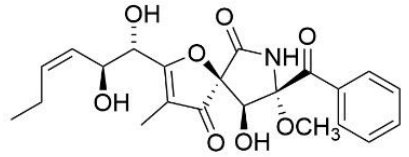

64<smiles>CC/C=C\[C@H](O)[C@@H](O)C1=C(C)C(=O)[C@@]2(O1)C(=O)N[C@](OC)(C(=O)c1ccccc1)[C@H]2O</smiles>

65<smiles>C=C[C@]1(C)C=C2C(=O)C(O)=C3C(C)(C)CCC[C@]3(C)[C@]2(C)CC1</smiles>

68

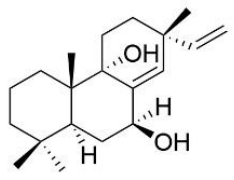

69<smiles>CC/C=C\[C@H](O)[C@@H](O)C1=C(C)C(=O)[C@]2(NC(=O)[C@]3(O2)C(=O)N[C@](OC)(C(=O)c2ccccc2)[C@@H]3O)C1=O</smiles>

66

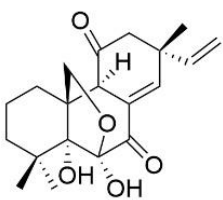

67

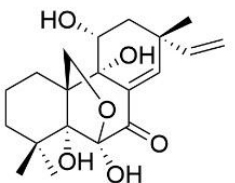

72

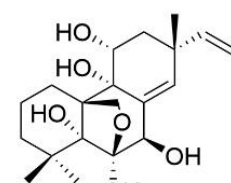

ŌH

73

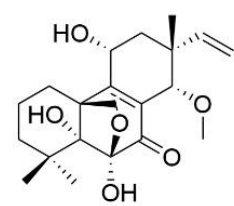

70

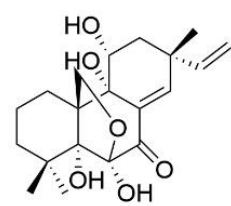

71

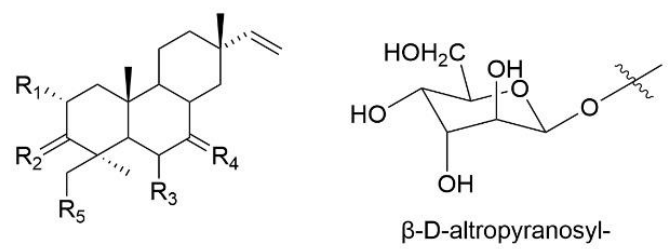

$\begin{array}{lcccccc} & \mathrm{R}_{1} & \mathrm{R}_{2} & \mathrm{R}_{3} & \mathrm{R}_{4} & \mathrm{R}_{5} & \\ 76 & \mathrm{OH} & \mathrm{H}, \beta-\mathrm{OH} & \mathrm{H} & \mathrm{O} & \beta \text {-D-altropyranosyl- } & \Delta^{8,9} \\ 77 & \mathrm{OH} & \mathrm{H}, \beta-\mathrm{OH} & \beta-\mathrm{OH} & \mathrm{H}, \mathrm{H} & \beta \text {-D-altropyranosyl- } & \Delta^{7,8} \\ 107 & \mathrm{OH} & \mathrm{H}, \beta-\mathrm{OH} & \mathrm{H} & \mathrm{H}, \mathrm{H} & \beta \text {-D-altropyranosyl- } & \Delta^{7,8} \\ 108 & \mathrm{H} & \mathrm{H}, \beta-\mathrm{OH} & \mathrm{H} & \mathrm{H}, \mathrm{H} & \beta \text {-D-altropyranosyl- } & \Delta^{7,8} \\ 109 & \mathrm{H} & \mathrm{O} & \mathrm{H} & \mathrm{H}, \mathrm{H} & \beta \text {-D-altropyranosyl- } & \Delta^{7,8}\end{array}$

Figure 2. Cont. 


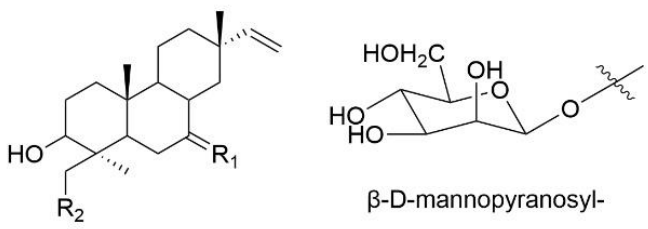

$\mathrm{R}_{1}$

$\mathrm{R}_{2}$

$\begin{array}{cccc}78 & \mathrm{H}, \alpha-\mathrm{OH} & \beta \text {-D-altropyranosyl- } & \Delta^{8,14} \\ \mathbf{7 9} & \mathrm{O} & \beta \text {-D-altropyranosyl- } & \Delta^{8,9} \\ \mathbf{8 0} & \mathrm{H} & \beta \text {-D-mannopyranosyl- } & \Delta^{7,8}\end{array}$<smiles>[R]CC1(C)C([R])C([R])CC2(C)C3CCC(C)(C=C)CC3C([R9])CC12</smiles>

$\begin{array}{lcccll} & \mathrm{R}_{1} & \mathrm{R}_{2} & \mathrm{R}_{3} & \mathrm{R}_{4} & \\ \mathbf{8 1} & \mathrm{OH} & \mathrm{H}, \beta-\mathrm{OH} & \mathrm{H} & \alpha \text {-D-glucopyranosyl(1-6)- } \beta \text {-D-altropyranosyl- } & \Delta^{7,8} \\ \mathbf{8 5} & \mathrm{H} & \mathrm{O} & \mathrm{H}, \alpha-\mathrm{OH} & \beta \text {-D-altropyranosyl- } & \Delta^{8,14} \\ \mathbf{8 6} & \mathrm{H} & \mathrm{O} & \mathrm{O} & \beta \text {-D-altropyranosyl- } & \Delta^{8,9} \\ \mathbf{8 7} & \mathrm{H} & \mathrm{O} & \mathrm{O} & \beta \text {-D-altropyranosyl- } & \Delta^{8,14}\end{array}$

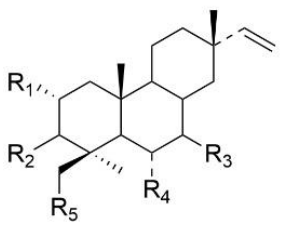
$\mathrm{R}_{1} \quad \mathrm{R}_{2}$
$\mathrm{R}_{3} \quad \mathrm{R}_{4} \quad \mathrm{R}_{5}$
$88 \mathrm{OH} \quad \mathrm{H}, \beta-\mathrm{OH}$
O $\quad H \quad \beta$-D-altropyranosyl- $\quad \Delta^{8,14}$
$89 \mathrm{OH} \quad \mathrm{H}, \beta-\mathrm{OH}$
$H \quad O H \quad \beta$-D-altropyranosyl-
$\begin{array}{ccc}\mathrm{OH} & \beta \text {-D-altropyranosyl- } & \Delta^{7,8} \\ \mathrm{H} & \beta \text {-D-altropyranosyl- } & \Delta^{8,9}\end{array}$
$90 \mathrm{OH} \quad \mathrm{H}, \beta-\mathrm{OH}$
$\mathrm{H}, \mathrm{a}-\mathrm{OH}$<smiles>[R]C1=C([R])C2C(C)(CC(O)[C@H](O)C2(C)C)C2CCC(C)(C=C)CC12</smiles>

$\begin{array}{cc}\mathrm{R}_{1} & \mathrm{R} \\ \mathrm{H} & \mathrm{H} \\ \mathrm{H}, \mathrm{H} & \mathrm{O} \\ \mathrm{H}, \mathrm{H} & \mathrm{H} \\ \mathrm{O} & \mathrm{H}\end{array}$

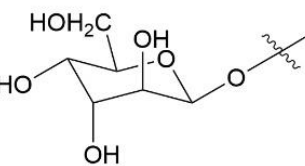

${ }^{4} C_{1} \quad \beta$-D-altropyranosyl-

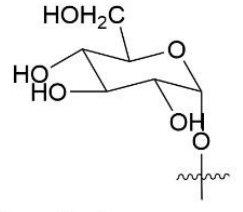

${ }^{4} C_{1}$ a-D-glucopyranosyl-

\section{$\Delta^{8,14}$

$\mathrm{R}_{3}$

\begin{tabular}{|c|c|}
\hline $\mathrm{R}_{3}$ & \\
\hline$\alpha$-D-glucopyranosyl-(1 $\rightarrow 6)-\beta$-D-altropyranosyl- & $\Delta^{6,8(14)}$ \\
\hline$\alpha$-D-glucopyranosyl-(1 $\rightarrow 6)-\beta$-D-altropyranosyl- & $\Delta^{8,9}$ \\
\hline D-glucopyranosyl-(1 $\rightarrow 4)-\beta-D$ & $\Delta^{7,8}$ \\
\hline$\beta$-D-altropyranosyl-, ${ }^{4} C_{1}$ & $\Delta^{7,8}$ \\
\hline
\end{tabular}

Figure 2. Cont. 


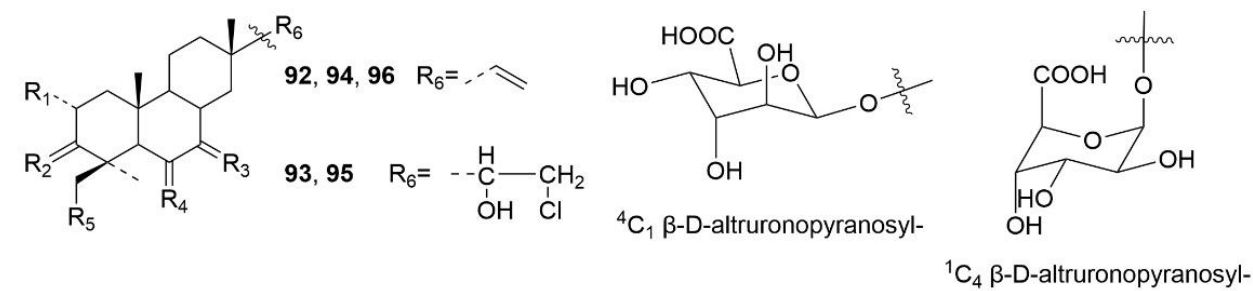

$\begin{array}{lcccccl} & \mathrm{R}_{1} & \mathrm{R}_{2} & \mathrm{R}_{3} & \mathrm{R}_{4} & \mathrm{R}_{5} & \Delta \\ 92 & \mathrm{H} & \mathrm{O} & \mathrm{H} & \mathrm{H}, \mathrm{H} & \beta \text {-D-altruronopyranosyl-, }{ }^{4} \mathrm{C}_{1} & \Delta^{7} \\ 93 & \mathrm{H} & \mathrm{O} & \mathrm{H} & \mathrm{H}, \mathrm{H} & \beta \text {-D-altruronopyranosyl-, }{ }^{4} \mathrm{C}_{1} & \Delta^{7} \\ 94 & \mathrm{H} & \mathrm{H}, \beta-\mathrm{OH} & \mathrm{H}, \mathrm{\alpha}-\mathrm{OH} & \mathrm{H}, \mathrm{H} & \beta \text {-D-altruronopyranosyl-, }{ }^{4} \mathrm{C}_{1} & \Delta^{8(14)} \\ 95 & \mathrm{OH} & \mathrm{H}, \beta-\mathrm{OH} & \mathrm{H} & \mathrm{H}, \mathrm{H} & \beta \text {-D-altruronopyranosyl-, }{ }^{1} \mathrm{C}_{4} & \Delta^{7} \\ 96 & \mathrm{OH} & \mathrm{H}, \beta-\mathrm{OH} & \mathrm{H} & \mathrm{H} & \beta \text {-D-altruronopyranosyl-, }{ }^{1} \mathrm{C}_{4} & \Delta^{6,8(14)}\end{array}$

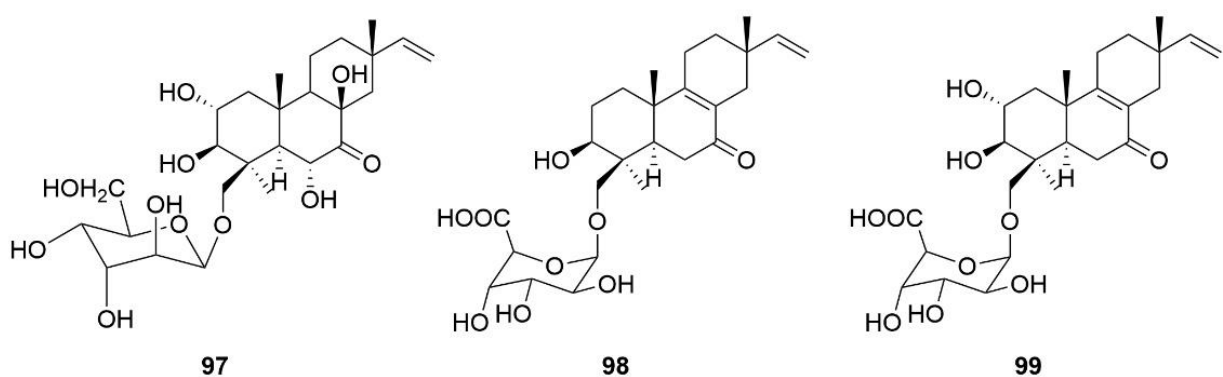

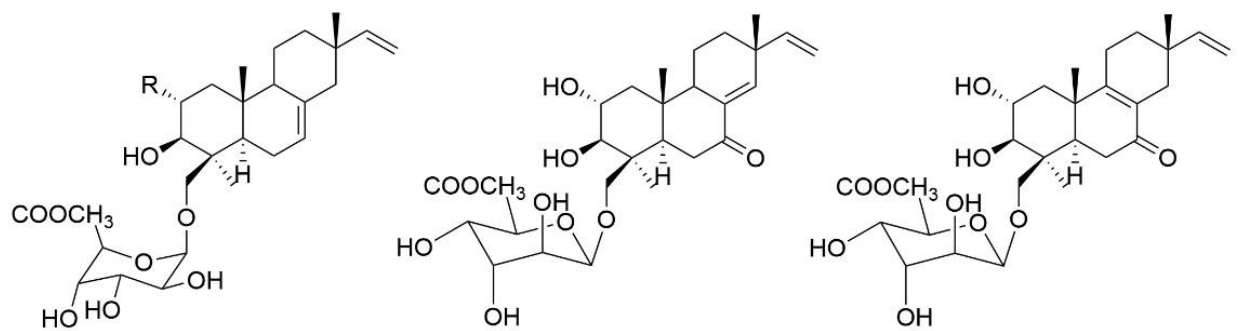

$100 \mathrm{R}=\mathrm{H}$

$101 \mathrm{R}=\mathrm{OH}$

102

103

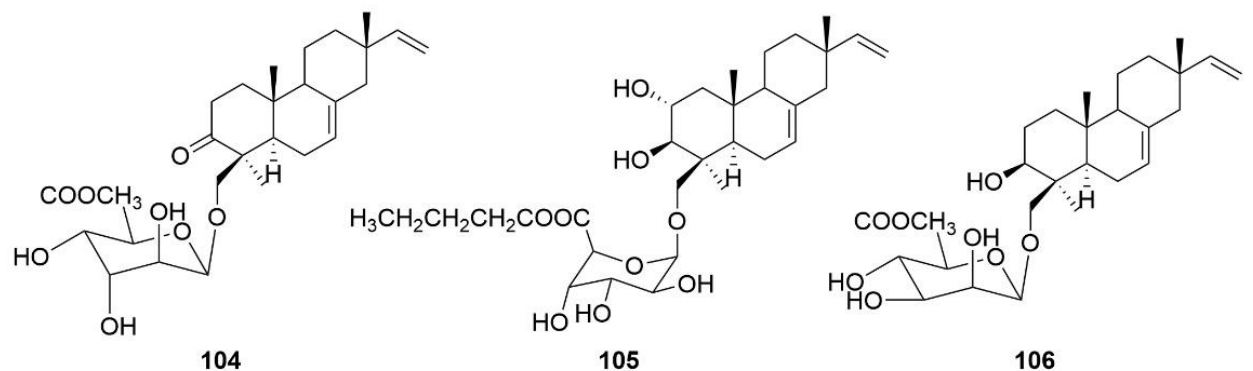

104

105

106

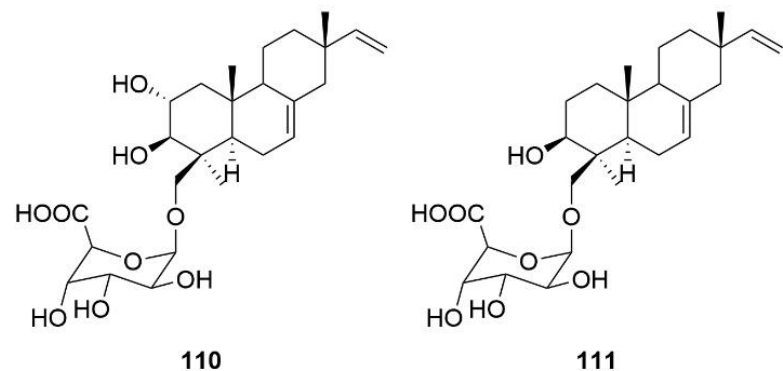

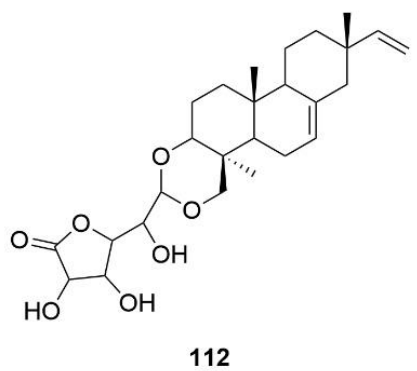

Figure 2. Cont. 
<smiles>C=CC1(C)CCC2C(=CC[C@@H]3C[C@@]2(C)C[C@@H](O)[C@H]3O)C1</smiles>

113<smiles>N[C@@H](Cc1ccccc1)C(=O)N1CCC[C@H]1C=O</smiles>

114<smiles>CSCC[C@H](N)C(=O)N1CCC[C@H]1C=O</smiles>

115<smiles>NC(Cc1ccc(O)cc1)C(=O)N1CCCC1C=O</smiles>

116<smiles>CC(C)[C@H](N)C(=O)N1CCC[C@H]1C(=O)[In]</smiles><smiles>CC(C)[C@H](N)C(=O)NCC(=O)O</smiles><smiles>CC(C)C[C@H](N)C(=O)N1CCC[C@H]1C=O</smiles><smiles>COc1cc(O)c(C)c2c1COC(C)C2</smiles><smiles>CC(C)C(C)/C=C\C(C)C1CCC2C3C(=O)CC4CC(O)CCC4(C)C3CCC12C</smiles>

122<smiles>O=C(O)CCC(=O)O</smiles>

123<smiles>CCCc1cccc(O)c1C(=O)O</smiles>

124<smiles>CC(=O)c1c(O)c(C)c(C)c2c1C(C)C(=O)O2</smiles>

125<smiles>CC(O)Cc1cccc(O)c1C(=O)O</smiles>

126<smiles></smiles>

127<smiles>CC=C(C)c1c(Cl)c(O)c(C)c2c1Oc1cc(O)c(Cl)c(C)c1C(=O)O2</smiles>

128<smiles>COC(=O)C1(c2ccc3c(c2)CC(C(C)(C)O)O3)OC(=O)C(O)=C1c1ccc(O)cc1</smiles>

129<smiles>COC(=O)C1(Cc2ccc(O)c(CC=CC(C)C)c2)OC(=O)C(O)=C1c1ccc(O)cc1</smiles>

130<smiles>CC(=O)c1c(C)cc(O)cc1O</smiles>

132<smiles>[R]C([R])(C)Cc1cc(=O)c2c(C)cc(O)cc2o1</smiles>

$136 \mathrm{R}_{1}+\mathrm{R}_{2}=\mathrm{O}$ $137 \mathrm{R}_{1}=\mathrm{OH}, \mathrm{R}_{2}=\mathrm{H}$<smiles>COC(=O)C1(c2ccc(O)c(CCC(C)(C)O)c2)OC(=O)C(O)=C1c1ccc(O)cc1</smiles>

131<smiles>[R]c1c(C)cc(Oc2cc(C)cc(O)c2)cc1O</smiles>

133<smiles>CC(C)c1cn2c3[nH]cnc3c(=O)n(C)c2n1</smiles>

138<smiles>[R]CC1NC(=O)[C@@H](Cc2c[nH]c3ccccc23)NC1=O</smiles>

$139 \mathrm{R}=$ phenyl 140 R=isopropyl

Figure 2. Cont. 

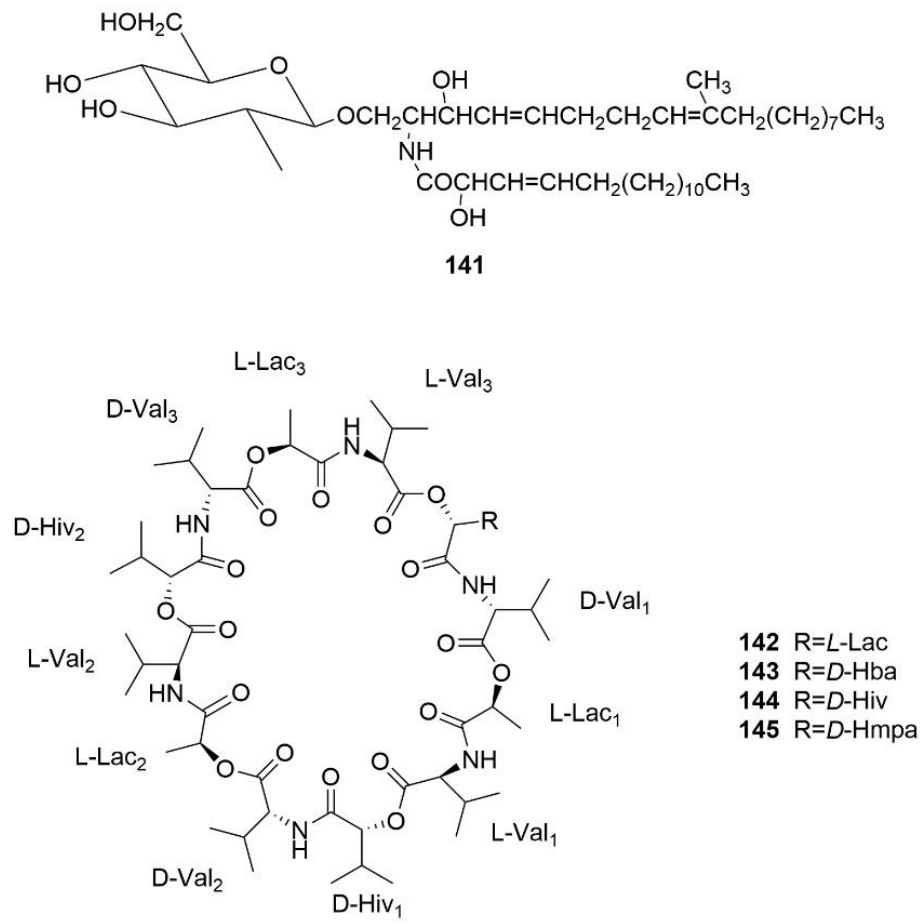

Figure 2. Chemical structures of the 145 compounds isolated from sea-cucumber-associated microorganisms.

\subsection{Summary of the Natural Products Isolated from Microorganisms Associated with} Sea Cucumbers

From 2000 to 2021, 145 natural products were isolated from microorganisms associated with sea cucumbers. The numbers of compounds isolated in 2008, 2014, and 2020 were significantly higher than the numbers isolated in other years (Figure 3). The compounds isolated from sea-cucumber-associated microorganisms are mainly polyketides, alkaloids, and terpenoids (Figures 4 and 5), which account for $28 \%, 18 \%$, and $32 \%$ of the total isolated compounds, respectively (Figure 4). Most of these compounds were isolated from seacucumber-associated fungi (Figure 4), and many of them have demonstrated bioactivities, including cytotoxicity, antimicrobial, enzyme-inhibiting, antiviral, and antiangiogenic activities, and the downregulation of ROS and NO production (Figure 6).

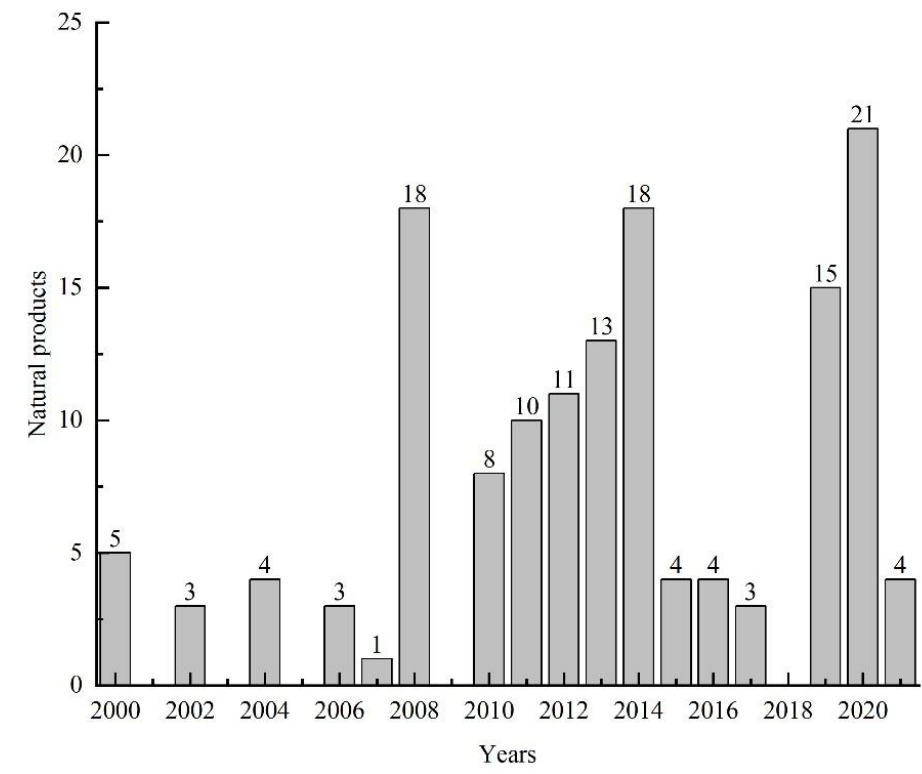

Figure 3. Natural products isolated from sea-cucumber-associated microorganisms from 2000 to 2021. 


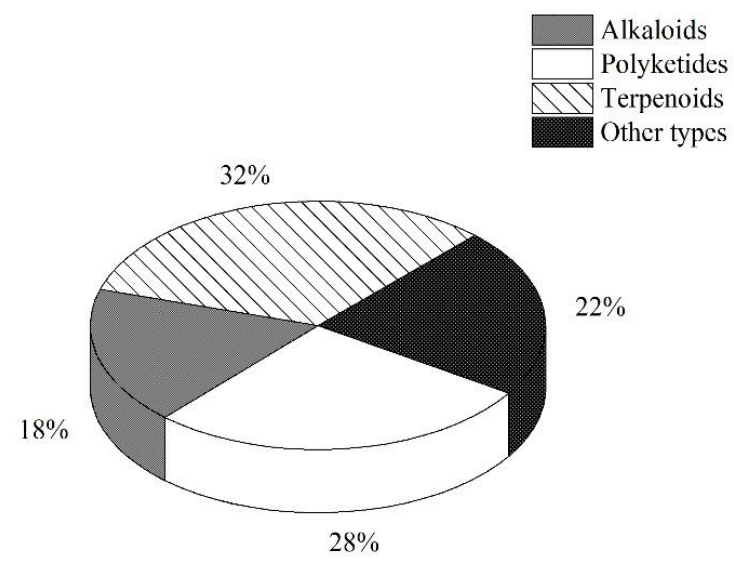

Figure 4. Percentage distribution of the natural products isolated from sea-cucumber-associated microorganisms.

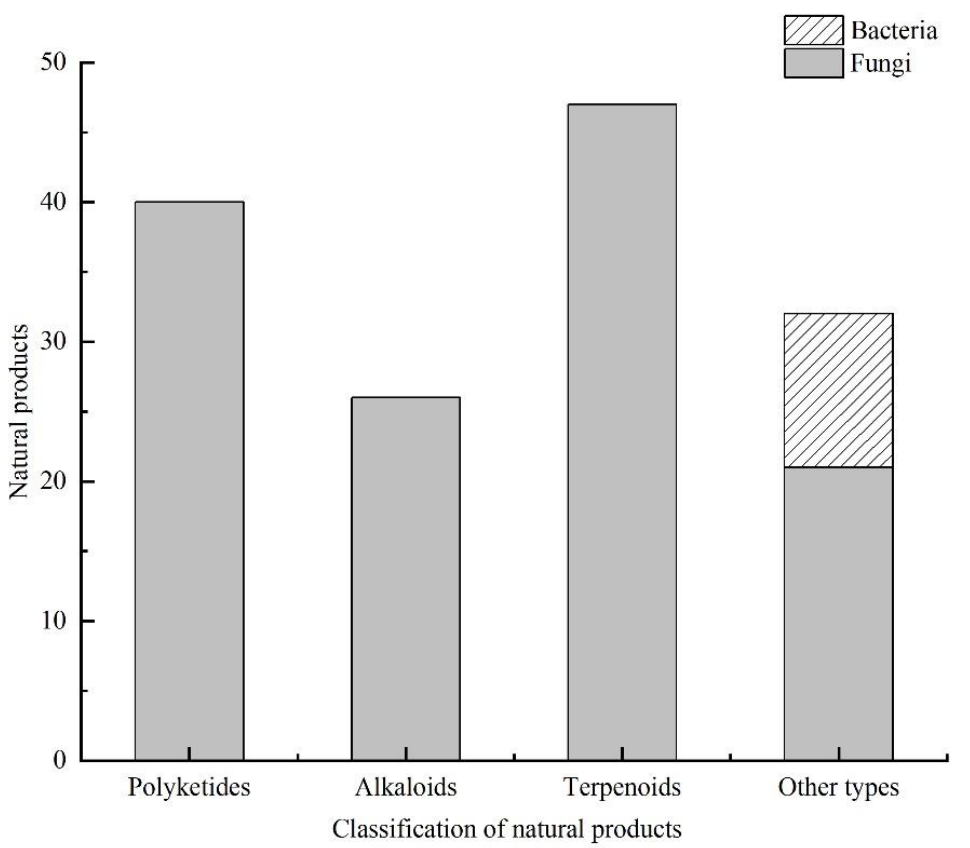

Figure 5. Natural products isolated from sea-cucumber-associated microorganisms.

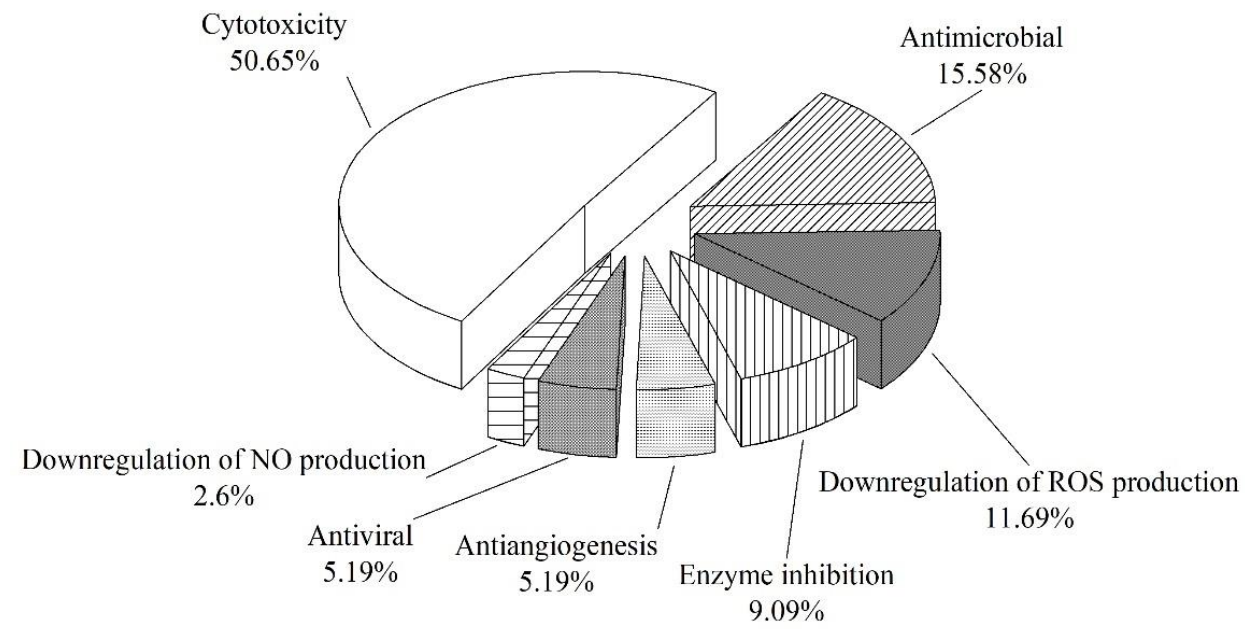

Figure 6. Percentage distribution of the bioactivities of the natural products isolated from sea-cucumber-associated microorganisms. 


\section{Conclusions}

Sea cucumbers have been extensively utilized in medicine in Asia for a long time, and a variety of compounds with pharmacological activities have been isolated from sea cucumbers [10]. The actual producers of these marine natural products may be seacucumber-associated microorganisms. Sea cucumbers harbor a rich and diverse assortment of microorganisms. Over the past 20 years, seventy-eight genera of bacteria belonging to 47 families in four phyla, and 29 genera of fungi belonging to 24 families in the phylum Ascomycota have been cultured from sea cucumbers. A total of 145 natural products have been isolated from sea-cucumber-associated microorganisms. These compounds are polyketides, terpenoids, alkaloids, and others, and many have been shown to have various biological activities. Sea-cucumber-associated microorganisms have great potential for the production and isolation of high-value bioactive compounds.

Supplementary Materials: The following are available online at https:/ / www.mdpi.com/article/10 $.3390 /$ md19080461/s1, Table S1. Microorganism genera associated with sea cucumbers.

Author Contributions: L.C. and G.-Y.W. conceived and designed the format of the manuscript. L.C., X.-Y.W. and R.-Z.L. analyzed the data and drafted and edited the manuscript. X.-Y.W. drew the chemical structure of compounds. L.C. and G.-Y.W. reviewed the manuscript. All the authors contributed in terms of critical reading and discussion of the manuscript. All authors have read and agreed to the published version of the manuscript.

Funding: This study was funded by the Discipline Construction Guide Foundation in Harbin Institute of Technology at Weihai (No. WH20150204 and No. WH20160205), and the Research Innovation Foundation in Harbin Institute of Technology at Weihai (No. 2019KYCXJJYB15).

Conflicts of Interest: The authors declare no conflict of interest.

\section{References}

1. Kiew, P.L.; Don, M.M. Jewel of the seabed: Sea cucumbers as nutritional and drug candidates. Int. J. Food Sci. Nutr. 2012, 63, 616-636. [CrossRef]

2. Mondol, M.A.M.; Shin, H.J.; Rahman, M.A.; Islam, M.T. Sea cucumber glycosides: Chemical structures, producing species and important biological properties. Mar. Drugs 2017, 15, 317. [CrossRef]

3. Bordbar, S.; Anwar, F.; Saari, N. High-value components and bioactives from sea cucumbers for functional foods-A review. Mar. Drugs 2011, 9, 1761-1805. [CrossRef] [PubMed]

4. Zhang, X.; Nakahara, T.; Miyazaki, M.; Nogi, Y.; Taniyama, S.; Arakawa, O.; Inoue, T.; Kudo, T. Diversity and function of aerobic culturable bacteria in the intestine of the sea cucumber Holothuria leucospilota. J. Gen. Appl. Microbiol. 2012, 58, 447-456. [CrossRef]

5. Gao, F.; Li, F.; Tan, J.; Yan, J.; Sun, H. Bacterial community composition in the gut content and ambient sediment of sea cucumber Apostichopus japonicus revealed by $16 \mathrm{~S}$ rRNA gene pyrosequencing. PLoS ONE 2014, 9, e100092. [CrossRef]

6. Chen, L.; Du, S.; Qu, W.Y.; Guo, F.R.; Wang, G.Y. Biosynthetic potential of culturable bacteria associated with Apostichopus japonicus. J. Appl. Microbiol. 2019, 127, 1686-1697. [CrossRef] [PubMed]

7. Jung, D.; Seo, E.Y.; Epstein, S.S.; Joung, Y.; Han, J.; Parfenova, V.V.; Belykh, O.I.; Gladkikh, A.S.; Ahn, T.S. Application of a new cultivation technology, I-tip, for studying microbial diversity in freshwater sponges of Lake Baikal, Russia. FEMS Microbiol. Ecol. 2014, 90, 417-423. [CrossRef] [PubMed]

8. Wargasetia, T.L. Mechanisms of cancer cell killing by sea cucumber-derived compounds. Investig. New Drugs 2017, 35, 820-826. [CrossRef] [PubMed]

9. Taiyeb-Ali, T.B.; Zainuddin, S.L.; Swaminathan, D.; Yaacob, H. Efficacy of 'Gamadent' toothpaste on the healing of gingival tissues: A preliminary report. J. Oral Sci. 2003, 45, 153-159. [CrossRef]

10. Shi, S.; Feng, W.; Hu, S.; Liang, S.; An, N.; Mao, Y. Bioactive compounds of sea cucumbers and their therapeutic effects. Chin. J. Oceanol. Limnol. 2016, 34, 549-558. [CrossRef]

11. Hossain, A.; Dave, D.; Shahidi, F. Northern sea cucumber (Cucumaria frondosa): A potential candidate for functional food, nutraceutical, and pharmaceutical sector. Mar. Drugs 2020, 18, 274. [CrossRef]

12. Chari, A.; Mazumder, A.; Lau, K.; Catamero, D.; Galitzeck, Z.; Jagannath, S. A phase II trial of TBL-12 sea cucumber extract in patients with untreated asymptomatic myeloma. Br. J. Haematol. 2018, 180, 296-298. [CrossRef] [PubMed]

13. Schmidt, E.W. The secret to a successful relationship: Lasting chemistry between ascidians and their symbiotic bacteria. Invertebr. Biol. 2015, 134, 88-102. [CrossRef] [PubMed]

14. Bewley, C.A.; Holland, N.D.; Faulkner, D.J. Two classes of metabolites from Theonella swinhoei are localized in distinct populations of bacterial symbionts. Experientia 1996, 52, 716-722. [CrossRef] 
15. Bewley, C.A.; Faulkner, D.J. Lithistid sponges: Star performers or hosts to the stars. Angew. Chem. Int. Ed. 1998, 37, $2162-2178$. [CrossRef]

16. Piel, J. Metabolites from symbiotic bacteria. Nat. Prod. Rep. 2004, 21, 519-538. [CrossRef]

17. Zhang, X.; Nakahara, T.; Murase, S.; Nakata, H.; Inoue, T.; Kudo, T. Physiological characterization of aerobic culturable bacteria in the intestine of the sea cucumber Apostichopus japonicus. J. Gen. Appl. Microbiol. 2013, 59, 1-10. [CrossRef]

18. Kurahashi, M.; Fukunaga, Y.; Sakiyama, Y.; Harayama, S.; Yokota, A. Iamia majanohamensis gen. nov., sp. nov., an actinobacterium isolated from sea cucumber Holothuria edulis, and proposal of Iamiaceae fam. nov. Int. J. Syst. Evol. Microbiol. 2009, 59, 869-873. [CrossRef]

19. Gozari, M.; Bahador, N.; Jassbi, A.R.; Mortazavi, M.S.; Eftekhar, E. Antioxidant and cytotoxic activities of metabolites produced by a new marine Streptomyces sp. isolated from the sea cucumber Holothuria leucospilota. Iran. J. Fish. Sci. 2018, 17, 413-426. [CrossRef]

20. Pivkin, M.V. Filamentous fungi associated with holothurians from the Sea of Japan, off the primorye coast of Russia. Biol. Bull. 2000, 198, 101-109. [CrossRef]

21. Afiyatullov, S.S.; Kuznetsova, T.A.; Isakov, V.V.; Pivkin, M.V.; Prokof'eva, N.G.; Elyakov, G.B. New diterpenic altrosides of the fungus Acremonium striatisporum isolated from a sea cucumber. J. Nat. Prod. 2000, 63, 848-850. [CrossRef]

22. Marchese, P.; Garzoli, L.; Gnavi, G.; O'Connell, E.; Bouraoui, A.; Mehiri, M.; Murphy, J.M.; Varese, G.C. Diversity and bioactivity of fungi associated with the marine sea cucumber Holothuria poli: Disclosing the strains potential for biomedical applications. J. Appl. Microbiol. 2020, 129, 612-625. [CrossRef]

23. Gong, J.; Tang, H.; Geng, W.L.; Liu, B.S.; Sun, P.; Li, L.; Li, Z.Y.; Zhang, W. Cyclic dipeptides in actinomycete Brevibacterium sp. associated with sea cucumber Apostichopus japonicus Selenka: Isolation and identification. Acad. J. Second Mil. Med. Univ. 2012, 33, 1284-1287. (In Chinese) [CrossRef]

24. Enomoto, M.; Nakagawa, S.; Sawabe, T. Microbial communities associated with Holothurians: Presence of unique bacteria in the coelomic fluid. Microbes Environ. 2012, 27, 300-305. [CrossRef] [PubMed]

25. Wibowo, J.T.; Kellermann, M.Y.; Versluis, D.; Putra, M.Y.; Murniasih, T.; Mohr, K.I.; Wink, J.; Engelmann, M.; Praditya, D.F.; Steinmann, E.; et al. Biotechnological potential of bacteria isolated from the sea cucumber Holothuria leucospilota and Stichopus vastus from Lampung, Indonesia. Mar. Drugs 2019, 17, 635. [CrossRef]

26. Alipiah, N.M.; Ramli, N.H.S.; Low, C.F.; Shamsudin, M.N.; Yusoff, F.M. Protective effects of sea cucumber surface-associated bacteria against Vibrio harveyi in brown-marbled grouper fingerlings. Aquacult. Environ. Interact. 2016, 8, 147-155. [CrossRef]

27. Xia, X.; Qi, J.; Wei, F.; Jia, A.; Yuan, W.; Meng, X.; Zhang, M.; Liu, C.; Wang, C. Isolation and characterization of a new Benzofuran from the fungus Alternaria sp. (HS-3) associated with a sea cucumber. Nat. Prod. Commun. 2011, 6, 1913-1914. [CrossRef] [PubMed]

28. Liu, C.H.; Xia, X.K.; Qi, J.; Zhang, Y.G.; Yuan, W.P.; Meng, X.M.; Jia, A.R.; Sun, Y.J.; Hu, W. The secondary metabolites of the HS-3 Alternaria sp. fungus associated with holothurians. J. Chin. Med. Mater. 2010, 33, 1875-1877. (In Chinese) [CrossRef]

29. Qi, J.; Jiang, L.; Zhao, P.; Chen, H.; Jia, X.; Zhao, L.; Dai, H.; Hu, J.; Liu, C.; Shim, S.H.; et al. Chaetoglobosins and azaphilones from Chaetomium globosum associated with Apostichopus japonicus. Appl. Microbiol. Biotechnol. 2020, 104, 1545-1553. [CrossRef]

30. Farouk, A.E.; Ghouse, F.A.H.; Ridzwan, B.H. New bacterial species isolated from malaysia sea cucumbers with optimized secreted antibacterial activity. Am. J. Biochem. Biotechnol. 2007, 3, 60-65.

31. Kamarudin, K.R. Microbial population in the coelomic fluid of Stichopus chloronotus and Holothuria (Mertensiothuria) leucospilota collected from Malaysian waters. Sains Malays. 2014, 43, 1013-1021.

32. Li, Z.; Huang, X.S.; Zheng, B.D.; Deng, K.B. Biodiversity analysis and pathogen inhibition mechanism of the endogenous bacteria in Fujian Apostichopus japonicus. Sci. Technol. Food Ind. 2018, 39, 137-141, 170. (In Chinese) [CrossRef]

33. Bogatyrenko, E.A.; Buzoleva, L.S. Characterization of the gut bacterial community of the Japanese sea cucumber Apostichopus japonicus. Microbiology 2016, 85, 116-123. [CrossRef]

34. Jo, J.; Choi, H.; Lee, S.-G.; Oh, J.; Lee, H.-G.; Park, C. Draft genome sequences of Pseudoalteromonas tetraodonis CSB01KR and Pseudoalteromonas lipolytica CSB02KR, isolated from the gut of the sea cucumber Apostichopus japonicus. Genome Announc. 2017, 5, e00627-17. [CrossRef]

35. Tan, J.J.; Liu, X.Y.; Yang, Y.; Li, F.H.; Tan, C.H.; Li, Y.M. Aspergillolide, a new 12-membered macrolide from sea cucumber-derived fungus Aspergillus sp. S-3-75. Nat. Prod. Res. 2020, 34, 1131-1137. [CrossRef]

36. Hu, Y.; Yang, M.; Zhao, J.; Liao, Z.; Qi, J.; Wang, X.; Jiang, W.; Xia, X. A Meroterpenoid isolated from the fungus Aspergillus sp. Nat. Prod. Commun. 2019, 14, 1-3. [CrossRef]

37. Sun, P.; Xu, D.X.; Mandi, A.; Kurtan, T.; Li, T.J.; Schulz, B.; Zhang, W. Structure, absolute configuration, and conformational study of 12-membered macrolides from the fungus Dendrodochium sp. associated with the sea cucumber Holothuria nobilis Selenka. J. Org. Chem. 2013, 78, 7030-7047. [CrossRef] [PubMed]

38. Wang, X.D.; Sun, P.; Xu, D.X.; Tang, H.; Liu, B.S.; Zhang, W. Identification of secondary metabolites of the fungus Phialemonium sp. associated with the South China sea cucumber Holothuria nobilis Selenka. Acad. J. Second Mil. Med. Univ. 2014, 35, 988-991. (In Chinese) [CrossRef]

39. Xia, X.K.; Qi, J.; Liu, C.H.; Zhang, Y.G.; Jia, A.R.; Yuan, W.P.; Liu, X.; Zhang, M.S. Polyketones from Aspergillus terreus associated with Apostichopus japonicus. Mod. Food Sci. Technol. 2014, 30, 10-14, 62. (In Chinese) [CrossRef] 
40. Xia, X.; Zhang, J.; Zhang, Y.; Wei, F.; Liu, X.; Jia, A.; Liu, C.; Li, W.; She, Z.; Lin, Y. Pimarane diterpenes from the fungus Epicoccum sp. HS-1 associated with Apostichopus japonicus. Bioorg. Med. Chem. Lett. 2012, 22, 3017-3019. [CrossRef] [PubMed]

41. Wang, F.; Fang, Y.; Zhu, T.; Zhang, M.; Lin, A.; Gu, Q.; Zhu, W. Seven new prenylated indole diketopiperazine alkaloids from holothurian-derived fungus Aspergillus fumigatus. Tetrahedron 2008, 64, 7986-7991. [CrossRef]

42. Wang, F.-Z.; Zhang, M.; Sun, W.; Gu, Q.-Q.; Zhu, W.-M. 5a-Hydroxy-9-methoxy-11-(3-methyl-2-butenyl)-12-(2-methyl-1-propenyl)2,3,11,12-tetrahydro-1H,5H-pyrrolo $\left[1^{\prime \prime}, 2^{\prime \prime}: 4^{\prime}, 5^{\prime}\right]$ pyrazino $\left[1^{\prime}, 2^{\prime}: 1,6\right]$ pyrido[3,4-b]indole-5,6,14(5aH,14aH)-trione. Acta Crystallogr. Sect. E Struct. Rep. Online 2007, 63, o1859-o1860. [CrossRef]

43. Xia, X.K.; Liu, X.; Zhang, Y.G.; Yuan, W.P.; Zhang, M.S.; Wan, X.J.; Meng, X.M.; Liu, C.H. Study on the second metabolisms from fungus HS-1 Epicoccum spp. from the sea cucumber in Yellow Sea. J. Chin. Med. Mater. 2010, 33, 1577-1579. (In Chinese) [CrossRef]

44. Qi, J.; Zhao, P.; Zhao, L.; Jia, A.; Liu, C.; Zhang, L.; Xia, X. Anthraquinone derivatives from a sea cucumber-derived Trichoderma sp. fungus with antibacterial activities. Chem. Nat. Compd. 2020, 56, 112-114. [CrossRef]

45. Xia, X.; Liu, X.; Koo, D.C.; Sun, Z.; Shim, S. Chemical constituents of Fusarium sp. fungus associated with sea cucumbers. Chem. Nat. Compd. 2014, 50, 1103-1105. [CrossRef]

46. Afiyatullov, S.S.; Kalinovsky, A.I.; Antonov, A.S.; Zhuravleva, O.I.; Khudyakova, Y.V.; Aminin, D.L.; Yurchenko, A.N.; Pivkin, M.V. Isolation and structures of virescenosides from the marine-derived fungus Acremonium striatisporum. Phytochem. Lett. 2016, 15, 66-71. [CrossRef]

47. Qi, J.; Zhao, B.; Zhao, P.; Jia, A.; Zhang, Y.; Liu, X.; Liu, C.; Zhang, L.; Xia, X. Isolation and characterization of antiangiogenesis compounds from the fungus Aspergillus terreus associated with Apostichopus japonicus using zebrafish assay. Nat. Prod. Commun. 2017, 12, 261-262. [CrossRef]

48. Tae, H.; Sohng, J.K.; Park, K. MapsiDB: An integrated web database for type I polyketide synthases. Bioprocess. Biosyst. Eng. 2009, 32, 723-727. [CrossRef]

49. Risdian, C.; Mozef, T.; Wink, J. Biosynthesis of polyketides in Streptomyces. Microorganisms 2019, 7, 124. [CrossRef]

50. Hertweck, C. The biosynthetic logic of polyketide diversity. Angew. Chem. Int. Ed. 2009, 48, 4688-4716. [CrossRef]

51. Hussain, H.; Al-Sadi, A.M.; Schulz, B.; Steinert, M.; Khan, A.; Green, I.R.; Ahmed, I. A fruitful decade for fungal polyketides from 2007 to 2016: Antimicrobial activity, chemotaxonomy and chemodiversity. Future Med. Chem. 2017, 9, 1631-1648. [CrossRef]

52. Staunton, J.; Weissman, K.J. Polyketide biosynthesis: A millennium review. Nat. Prod. Rep. 2001, 18, 380-416. [CrossRef]

53. Xu, D.X.; Sun, P.; Kurtan, T.; Mandi, A.; Tang, H.; Liu, B.; Gerwick, W.H.; Wang, Z.W.; Zhang, W. Polyhydroxy cyclohexanols from a Dendrodochium sp. fungus associated with the sea cucumber Holothuria nobilis Selenka. J. Nat. Prod. 2014, 77, 1179-1184. [CrossRef] [PubMed]

54. Pavesi, C.; Flon, V.; Mann, S.; Leleu, S.; Prado, S.; Franck, X. Biosynthesis of azaphilones: A review. Nat. Prod. Rep. 2021, 38, 1058-1071. [CrossRef] [PubMed]

55. Schlager, S.; Drager, B. Exploiting plant alkaloids. Curr. Opin. Biotechnol. 2016, 37, 155-164. [CrossRef] [PubMed]

56. Desgagné-Penix, I. Distribution of alkaloids in woody plants. Plant Sci. Today 2017, 4, 137-142. [CrossRef]

57. Zotchev, S.B. Alkaloids from marine bacteria. Adv. Bot. Res. 2013, 68, 301-333. [CrossRef]

58. Souza, C.R.M.; Bezerra, W.P.; Souto, J.T. Marine alkaloids with anti-inflammatory activity: Current knowledge and future perspectives. Mar. Drugs 2020, 18, 147. [CrossRef] [PubMed]

59. Chen, J.; Zhang, W.; Guo, Q.; Yu, W.; Zhang, Y.; He, B. Bioactivities and future perspectives of Chaetoglobosins. J. Evid. Based Complement. Altern. Med. 2020, 2020, 8574084. [CrossRef]

60. Wang, F.-Z.; Li, D.-H.; Zhu, T.-J.; Zhang, M.; Gu, Q.-Q. Pseurotin $\mathrm{A}_{1}$ and $\mathrm{A}_{2}$, two new 1-oxa-7-azaspiro[4.4]non-2-ene-4,6-diones from the holothurian-derived fungus Aspergillus fumigatus WFZ-25. Can. J. Chem. 2011, 89, 72-76. [CrossRef]

61. Kim, S.K.; Li, Y.X. Biological activities and health effects of terpenoids from marine fungi. Adv. Food Nutr. Res. 2012, 65, 409-413. [CrossRef] [PubMed]

62. Yang, W.; Chen, X.; Li, Y.; Guo, S.; Wang, Z.; Yu, X. Advances in pharmacological activities of terpenoids. Nat. Prod. Commun. 2020, 15, 1-13. [CrossRef]

63. Gozari, M.; Alborz, M.; El-Seedi, H.R.; Jassbi, A.R. Chemistry, biosynthesis and biological activity of terpenoids and meroterpenoids in bacteria and fungi isolated from different marine habitats. Eur. J. Med. Chem. 2021, 210, 112957. [CrossRef] [PubMed]

64. Qi, J.; Xia, X.K.; Jia, A.R.; Liu, X.; Zhang, M.S.; Liu, C.H. Separation and preparation of chemical components from sea cucmberderived fungus Epicoccum sp. by two-dimensional high-throughput chromatography. Shandong Sci. 2015, 28, 14-18, 24. (In Chinese) [CrossRef]

65. Xia, X.; Qi, J.; Liu, Y.; Jia, A.; Zhang, Y.; Liu, C.; Gao, C.; She, Z. Bioactive isopimarane diterpenes from the fungus, Epicoccum sp. HS-1, associated with Apostichopus japonicus. Mar. Drugs 2015, 13, 1124-1132. [CrossRef]

66. Berrue, F.; McCulloch, M.W.; Kerr, R.G. Marine diterpene glycosides. Bioorg. Med. Chem. 2011, 19, 6702-6719. [CrossRef] [PubMed]

67. Afiyatullov, S.S.; Kalinovsky, A.I.; Kuznetsova, T.A.; Isakov, V.V.; Pivkin, M.V.; Dmitrenok, P.S.; Elyakov, G.B. New diterpene glycosides of the fungus Acremonium striatisporum isolated from a sea cucumber. J. Nat. Prod. 2002, 65, 641-644. [CrossRef]

68. Afiyatullov, S.S.; Kalinovsky, A.I.; Kuznetsova, T.A.; Pivkin, M.V.; Prokof'eva, N.G.; Dmitrenok, P.S.; Elyakov, G.B. New glycosides of the fungus Acremonium striatisporum isolated from a sea cucumber. J. Nat. Prod. 2004, 67, 1047-1051. [CrossRef] 
69. Afiyatullov, S.S.; Kalinovsky, A.I.; Pivkin, M.V.; Dmitrenok, P.S.; Kuznetsova, T.A. New diterpene glycosides of the fungus Acremonium striatisporum isolated from a sea cucumber. Nat. Prod. Res. 2006, 20, 902-908. [CrossRef]

70. Afiyatullov, S.S.; Kalinovsky, A.I.; Antonov, A.S. New Virescenosides from the marine-derived fungus Acremonium striatisporum. Nat. Prod. Commun. 2011, 6, 1063-1068. [CrossRef]

71. Zhuravleva, O.I.; Antonov, A.S.; Oleinikova, G.K.; Khudyakova, Y.V.; Popov, R.S.; Denisenko, V.A.; Pislyagin, E.A.; Chingizova, E.A.; Afiyatullov, S.S. Virescenosides from the Holothurian-associated fungus Acremonium striatisporum Kmm 4401. Mar. Drugs 2019, 17, 616. [CrossRef] [PubMed]

72. Wibowo, J.T.; Kellermann, M.Y.; Kock, M.; Putra, M.Y.; Murniasih, T.; Mohr, K.I.; Wink, J.; Praditya, D.F.; Steinmann, E.; Schupp, P.J. Anti-Infective and antiviral activity of valinomycin and its analogues from a sea cucumber-associated bacterium, Streptomyces sp. SV 21. Mar. Drugs 2021, 19, 81. [CrossRef] [PubMed] 